\title{
Understanding the characteristics of nonspecific binding of drug-like compounds to canonical stem-loop RNAs and their implications for functional cellular assays
}

\author{
MEGAN L. KELLY, ${ }^{1}$ CHIA-CHIEH CHU, ${ }^{1}$ HONGLUE SHI, ${ }^{2}$ LAURA R. GANSER, ${ }^{1,4}$ HAL P. BOGERD, ${ }^{3}$ \\ KELLY HUYNH, ${ }^{1}$ YUZE HOU, ${ }^{1}$ BRYAN R. CULLEN, ${ }^{3}$ and HASHIM M. AL-HASHIMI ${ }^{1,2}$ \\ ${ }^{1}$ Department of Biochemistry, ${ }^{2}$ Department of Chemistry, ${ }^{3}$ Department of Molecular Genetics and Microbiology, Center for Virology, \\ Duke University Medical Center, Durham, North Carolina 27710, USA
}

\begin{abstract}
Identifying small molecules that selectively bind an RNA target while discriminating against all other cellular RNAs is an important challenge in RNA-targeted drug discovery. Much effort has been directed toward identifying drug-like small molecules that minimize electrostatic and stacking interactions that lead to nonspecific binding of aminoglycosides and intercalators to many stem-loop RNAs. Many such compounds have been reported to bind RNAs and inhibit their cellular activities. However, target engagement and cellular selectivity assays are not routinely performed, and it is often unclear whether functional activity directly results from specific binding to the target RNA. Here, we examined the propensities of three drug-like compounds, previously shown to bind and inhibit the cellular activities of distinct stem-loop RNAs, to bind and inhibit the cellular activities of two unrelated HIV-1 stem-loop RNAs: the transactivation response element (TAR) and the rev response element stem IIB (RREIIB). All compounds bound TAR and RREIIB in vitro, and two inhibited TAR-dependent transactivation and RRE-dependent viral export in cell-based assays while also exhibiting off-target interactions consistent with nonspecific activity. A survey of X-ray and NMR structures of RNA-small molecule complexes revealed that aminoglycosides and drug-like molecules form hydrogen bonds with functional groups commonly accessible in canonical stem-loop RNA motifs, in contrast to ligands that specifically bind riboswitches. Our results demonstrate that drug-like molecules can nonspecifically bind stem-loop RNAs most likely through hydrogen bonding and electrostatic interactions and reinforce the importance of assaying for off-target interactions and RNA selectivity in vitro and in cells when assessing novel RNA-binders.
\end{abstract}

Keywords: TAR; RRE; RNA-ligand binding; RNA-targeted drug discovery; specificity; HIV-1

\section{INTRODUCTION}

RNA is an emerging class of attractive drug targets for a wide array of human diseases and pathogens (Connelly et al. 2016; Hermann 2016; Matsui and Corey 2017; Lieberman 2018; Warner et al. 2018). While there have been some successes in targeting RNAs with antisense oligonucleotides (ASOs) (Mendell et al. 2013; van Deutekom et al. 2013; Corey 2017), there is growing interest in developing small molecule inhibitors that can avoid delivery and safety limitations inherent to ASOs (Geary et al. 2015; Chi et al. 2017; Gagnon and Corey 2019). Despite some suc-

\footnotetext{
${ }^{4}$ Present address: Department of Biophysics, Johns Hopkins University, Baltimore, MD 21218, USA

Corresponding authors: hashim.al.hashimi@duke.edu, bryan.cullen@duke.edu

Article is online at http://www.rnajournal.org/cgi/doi/10.1261/ rna.076257.120.
}

cess in identifying compounds that bind RNAs and inhibit their activities in cells and even in animal models (Parsons et al. 2009; Palacino et al. 2015; Costales et al. 2017; Ratni et al. 2018), many challenges remain in targeting RNA with small molecules. Chief among them is identifying small molecules that can bind to an intended RNA target while discriminating against all other cellular RNAs (Thomas and Hergenrother 2008; Disney 2019).

Achieving high selectivity when targeting RNA with small molecules is particularly challenging because unlike proteins with their twenty amino acids, RNAs are composed of only four chemically similar nucleotides, and their

\footnotetext{
(C) 2021 Kelly et al. This article is distributed exclusively by the RNA Society for the first 12 months after the full-issue publication date (see http://rnajournal.cshlp.org/site/misc/terms.xhtml). After 12 months, it is available under a Creative Commons License (Attribution-NonCommercial 4.0 International), as described at http:// creativecommons.org/licenses/by-nc/4.0/.
} 
$3 \mathrm{D}$ structures are comprised of a smaller number of reoccurring motifs (Moore 1999; Bevilacqua et al. 2016; Miao and Westhof 2017). Moreover, RNAs are highly susceptible to forming strong electrostatic and stacking interactions that are inherently nonspecific. Indeed, aminoglycosides promiscuously bind RNA through electrostatic interactions (Wong et al. 1998; Walter et al. 1999; Verhelst et al. 2004) while intercalators bind to RNAs nonspecifically through hydrophobic and $\pi$-stacking interactions (Tanner and Cech 1985; White and Draper 1987; Tanious et al. 1992). Both are known to have many side effects when used clinically due to this nonspecific RNA binding (Xie et al. 2011; Callejo et al. 2015; Hong et al. 2015; Gunanathan Jayaraj et al. 2017). Additionally, many RNA drug targets lack tertiary structure and form highly flexible structures that can adaptively bind to a variety of small molecules (Hermann and Patel 2000; Bardaro et al. 2009; Stelzer et al. 2011).

Assessing cellular selectivity can also be challenging. While functional activity in cellular assays is often assumed to imply selectivity (Hermann 2016; Di Giorgio and Duca 2019), without studies measuring direct target engagement and functional selectivity in cells, cellular activity alone is not sufficient to establish a compound as a selective RNA-binder (Thorne et al. 2010; Rzuczek et al. 2017; Shin et al. 2017). Achieving selective RNA-binding in a cellular context is further complicated by the expression of the RNA target in the desired physiological state. The observed functional selectivity can vary depending on the cellular concentrations of the intended RNA target and unrelated RNAs that compete for binding. For example a small molecule targeting an RNA that is highly expressed may appear to be functionally selective but still bind many off-target RNAs causing detrimental side-effects, as is the case with nonselective aminoglycosides binding to highly abundant ribosomal RNA (Michael and Tor 1998; Walter et al. 1999; Verhelst et al. 2004).

Recent effort has focused on developing small molecules that minimize nonspecific electrostatic and stacking interactions to target RNA (Childs-Disney and Disney 2016; Hermann 2016; Warner et al. 2018) and that enjoy more favorable drug-like properties. However, additional studies are needed to assess which chemical properties if any favor selective RNA-binding. These more recently discovered drug-like RNA-binding molecules are thought to primarily engage RNA through a combination of shape complementarity and hydrogen bonding ( $\mathrm{H}$-bonding) (Warner et al. 2018; Di Giorgio and Duca 2019). Such compounds with demonstrated cellular activity have been enumerated in the RNA-Targeted Bioactive ligand Database (R-BIND) (Morgan et al. 2019) as well as the Inforna server (Disney et al. 2016) and the Nucleic Acid Ligand Database (NALDB) (Mishra and Kumar 2016). Some of these compounds have been shown to bind specific RNAs and inhibit their cellular activities with well-validated selectivity (Haga et al. 2015; Costales et al. 2017, 2019; Naro et al. 2018; Shi et al. 2019; Zhang et al. 2020). However, unlike aminoglycosides and intercalators, there are fewer in depth studies of selectivity for this class of drug-like RNA-binders particularly against stem-loop RNAs, which largely constitute the cellular transcriptome.

A common approach used to assess the in vitro RNA binding selectivity of drug-like compounds to stem-loop RNAs is to measure binding in the presence of excess tRNA or B-form DNA (Pascale et al. 2016; Ganser et al. 2018). However, neither tRNA nor B-DNA are good representatives of the structurally related and highly abundant RNA transcripts that compete for small molecule binding in the cell. Fewer studies have examined whether druglike molecules can discriminate against simple stem-loop RNAs, which are more representative of the transcriptome (Ironmonger et al. 2007; Duca et al. 2010; Sztuba-Solinska et al. 2014; Velagapudi et al. 2014). When these selectivity tests are performed, some level of nonspecific binding is often reported (Ironmonger et al. 2007; Duca et al. 2010; Sztuba-Solinska et al. 2014).

Similarly, in cell-based functional assays, controls to assess compound activity in the absence of the target RNA (off-target effects) or against a distinct RNA (cellular selectivity) are not always performed. When performed, druglike RNA-targeted small molecules are often found to have broad, promiscuous activity (Mischiati et al. 2001; Murchie et al. 2004; Nahar et al. 2014; Schmidt 2014) and/or to interact with assay reporter proteins (Thorne et al. 2010). Because few studies comprehensively report on the selectivity of these drug-like molecules at both the in vitro and cellular level (Mischiati et al. 2001; Richter et al. 2004; Zhang et al. 2020), it is unclear what capacity this new class of RNA-targeted compounds has to bind RNAs nonspecifically and what structural features define this behavior.

In this study, we evaluated the propensity of three compounds that are representatives of this new drug-like class of RNA binders to nonspecifically bind stem-loop RNAs containing bulges and internal loops. The compounds were DPQ, pentamidine, and yohimbine (Fig. 1A), which were previously shown to bind and inhibit the cellular activity of three different RNAs: the influenza A virus (IAV) promoter (Lee et al. 2014), CUG repeats (Warf et al. 2009), and the ferritin iron-response element (IRE) (Tibodeau et al. 2006), respectively. These compounds fulfill basic druglike criteria with DPQ and yohimbine having quantitative estimate of drug-likeness (QED) (Bickerton et al. 2012) values $>0.5$ (Supplemental Table S1). Pentamidine has a QED of $\sim 0.25$ due to some chemical properties that differ from the majority of FDA approved drugs such as its formal charge (Supplemental Table S1); however, this value is still higher than that of most aminoglycosides. We then assayed these small molecules for their activity against two unrelated RNAs that form stem-loop 
A

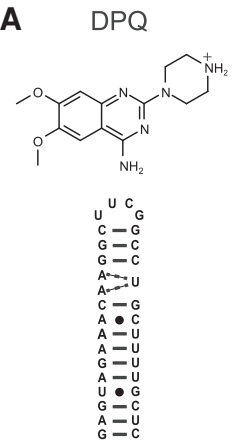

Influenza A

virus promoter

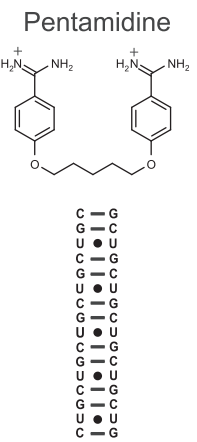

CUG

repeat

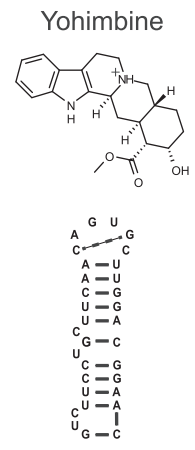

Ferritin iron-response element
B

\begin{tabular}{|c|c|}
\hline & ${ }_{G}^{G}{ }_{G}$ \\
\hline$U^{G} G_{G}$ & $U-A$ \\
\hline C...... & $\begin{array}{l}G=G \\
U-G\end{array}$ \\
\hline$C-G$ & $G-c$ \\
\hline $\begin{array}{l}G=C \\
A-U\end{array}$ & $\begin{array}{l}A-U \\
C-G\end{array}$ \\
\hline$G-C$ & $G \ldots c^{A}$ \\
\hline$c_{u}$ & $\begin{array}{l}C \cdots G \\
G \bullet G\end{array}$ \\
\hline $\begin{array}{l}A \cdots U \\
G-C\end{array}$ & $G \cdot A^{U}$ \\
\hline $\begin{array}{l}A=U \\
C\end{array}$ & $\begin{array}{l}G=C \\
U=A\end{array}$ \\
\hline$G-C$ & $G-C$ \\
\hline$G-C$ & \\
\hline HIV-1 & HIV-1 \\
\hline TAR & RRE IIB \\
\hline
\end{tabular}

FIGURE 1. Small molecules and RNA constructs used in this study. (A) Structures of three RNAbinding small molecules, displayed with protonation state predicted at $\mathrm{pH} 7.4$, from previous studies (Tibodeau et al. 2006; Warf et al. 2009; Lee et al. 2014) with the secondary structures of the RNAs they were previously reported to bind. (B) Secondary structures of HIV-1 TAR and RRE. JChemSuite was used for protonation state prediction at $\mathrm{pH}$ 7.4, JChemSuite 19.21.0, ChemAxon (https://www.chemaxon.com).

structures representative of the cellular transcriptome; the HIV-1 transactivation response element (TAR) (Puglisi et al. 1992) and stem IIB in the rev response element (RREIIB) (Fig. 1B; Malim et al. 1988, 1989, 1990; Chang and Sharp 1989).

DPQ was previously shown (Lee et al. 2014) to bind the IAV promoter in vitro and to inhibit replication of IAV $H 1 N 1$, IAV H3N2, and influenza B virus in cells with $E_{50}$ $\sim 72-276 \mu \mathrm{M}$. Little is known about the RNA binding specificity or off-target effects of DPQ. Pentamidine, which is an FDA-approved drug for several antimicrobial indications (Drake et al. 1985; Sarti 1989; Soto-Mancipe et al. 1993; Doua et al. 1996) and is known to bind several biologically important RNAs such as tRNA and the group I intron in vitro (Zhang 2002; Sun and Zhang 2008), was shown to inhibit MBNL1 binding to CUG RNA repeats in vitro with $I_{50} \sim 59 \mu \mathrm{M}$ (Warf et al. 2009), and to actively rescue splicing of pre-mRNAs regulated by MBNL1 in a CUG-dependent manner in cell-based assays and an animal model. Interestingly, in the absence of CUG repeat RNAs, pentamidine was shown to have opposite effects and this was attributed to nonspecific binding to an intron stem-loop RNA (Warf et al. 2009). A subsequent study showed that pentamidine's mechanism of action was more likely to be due to transcriptional inhibition of the RNA repeats (Coonrod et al. 2013). This indicates that pentamidine likely has broad nonspecific RNA-binding behavior that could extend to DNA and proteins as well, even though it initially displayed seemingly specific cellular inhibition. This behavior underscores the need for rigorous evaluation of target engagement in vitro and in cells when evaluating RNAbinding small molecules. Finally, yohimbine was shown to weakly bind the ferritin IRE in vitro with $K_{d} \sim 3.9 \mathrm{mM}$. Yet despite this weak binding affinity, yohimbine was shown get interactions in both cell-based assays indicating nonspecific binding. NMR chemical shift mapping combined with a structure-based survey reveals that the drug-like small molecules form $\mathrm{H}$-bonds with functional groups that are commonly accessible in stem-loop RNAs, and often associated with $\mathrm{Mg}^{2+}$ binding as well (Fig. 4). Our results show that even near-neutral and nonplanar drug-like compounds can promiscuously bind RNAs, most likely by $\mathrm{H}$-bonding and electrostatic interactions, and that nonspecific RNA-binders can appear to specifically inhibit their cellular activities if measurements of off-target interactions and cellular specificity are not performed.

\section{RESULTS}

\section{Small molecules bind to TAR and RREIIB in vitro}

We used solution state NMR spectroscopy to test binding of the three small molecules to TAR and RREIIB. 2D [ ${ }^{13} \mathrm{C}$, ${ }^{1} \mathrm{H}$ ] SOFAST-HMQC (Sathyamoorthy et al. 2014) experiments were recorded on uniformly ${ }^{13} \mathrm{C} /{ }^{15} \mathrm{~N}$ labeled TAR or RREIIB following addition of the small molecule to RNA. Surprisingly, all three small molecules resulted in distinct chemical shift perturbations (CSPs) for resonances across TAR (Fig. 2A) and RREIIB (Fig. 2B), with and without $\mathrm{Mg}^{2+}$, consistent with binding (Fig. 2; Supplemental Figs. S1-S3). For all molecules, the CSPs were larger for TAR (Fig. 2A) compared to RREIIB (Fig. 2B), which may reflect the higher flexibility of TAR, and a greater propensity to adapt its conformation to optimally bind different small molecules (Pitt et al. 2005; Bardaro et al. 2009; Stelzer et al. 2011).

The CSPs were observed throughout the TAR and RREIIB molecules. While these could reflect 

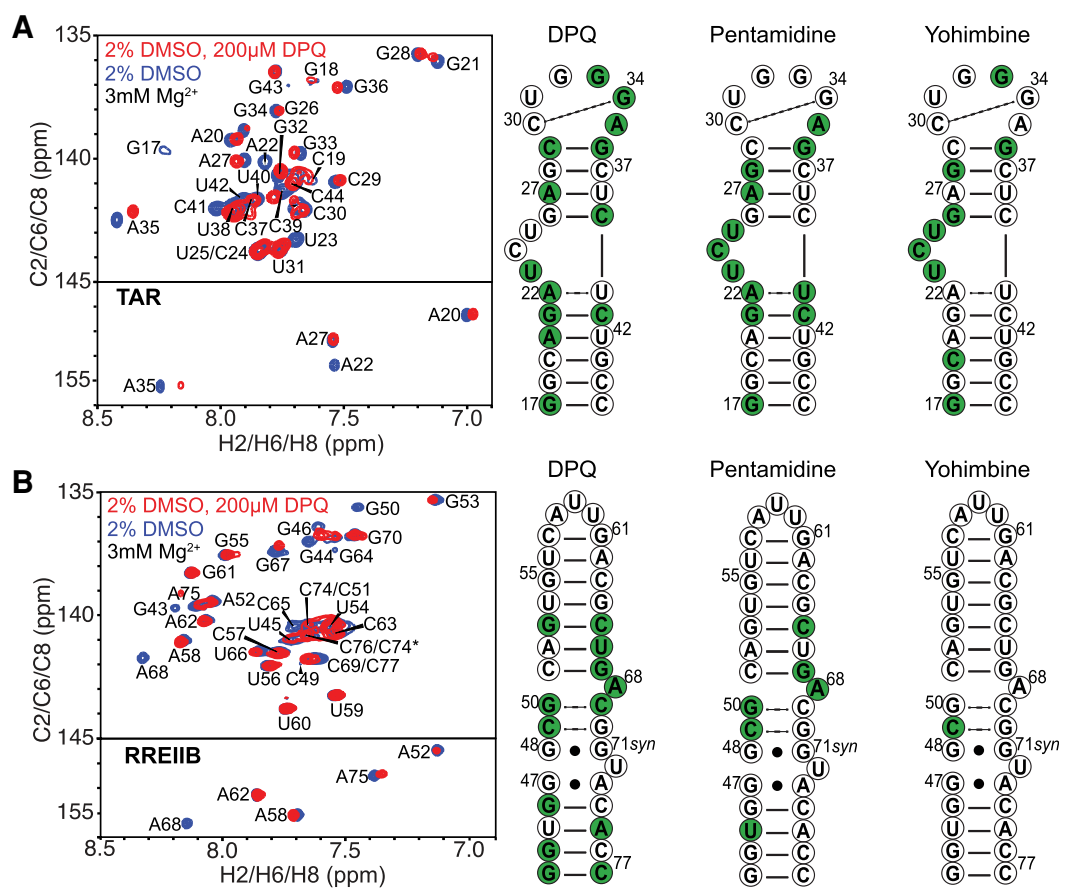

FIGURE 2. Testing small molecule binding to TAR and RREIIB using NMR chemical shift mapping experiments. Shown on the left are representative overlays of aromatic $2 \mathrm{D}\left[{ }^{13} \mathrm{C},{ }^{1} \mathrm{H}\right]$ SOFAST-HMOC (Sathyamoorthy et al. 2014) spectra for free and DPQ bound (A) TAR and (B) RREIIB showing chemical shift perturbations (CSPs) induced by DPQ. Buffer conditions were $15 \mathrm{mM} \mathrm{NaH} \mathrm{PO}_{4} / \mathrm{Na}_{2} \mathrm{HPO}_{4}, 25 \mathrm{mM} \mathrm{NaCl}, 0.1 \mathrm{mM}$ EDTA, $10 \%$ (v/v) $\mathrm{D}_{2} \mathrm{O}$ at $\mathrm{pH} 6.4$ and $3 \mathrm{mM} \mathrm{Mg}^{2+}$ added directly to sample. Also shown on the right are the secondary structures of TAR and RREIIB in which residues that have $<50 \%$ overlap between free and small moleculebound spectra, or are absent in the bound spectra, are colored green.

conformational changes arising from small molecule binding at a distal site, a recent study using TAR fragments showed that such CSPs arise from nonspecific binding across the entire RNA molecule (Orlovsky et al. 2020). Interestingly, the CSPs were smaller and more localized in the presence of $\mathrm{Mg}^{2+}$, possibly because $\mathrm{Mg}^{2+}$ competes with the small molecules for $\mathrm{H}$-bonding sites and electrostatic hotspots on the RNAs (Supplemental Figs. S1-S3; Holbrook et al. 1977; Hermann and Westhof 1998, 1999;
TAR and Tat-ARM peptide and found that all have measurable $I C_{50}$ S, indicating binding to TAR and displacement of the Tat-ARM peptide (Table 1; Supplemental Fig. S4A). Interestingly, in the RRE Rev-ARM peptide displacement assay, DPQ and pentamidine increased rather than decreased the fluorescence anisotropy in a dose-dependent manner (Supplemental Fig. S4B). This indicates that the compounds bind to the Rev-RREIIB complex without displacing the Rev peptide, and possibly increase

TABLE 1. $I C_{50} s$, apparent $K_{i} s$, and apparent $K_{d} s$ describing binding of each small molecule to TAR and RREIIB obtained from peptide displacement assays (see Materials and Methods)

\begin{tabular}{lllccc}
\hline $\begin{array}{l}\text { Small } \\
\text { molecule }\end{array}$ & $\begin{array}{c}\mathrm{IC}_{50} \text { TAR } \\
(\mu \mathrm{M})\end{array}$ & $\begin{array}{c}\mathrm{K}_{\mathrm{i}, \text { app }} \text { TAR } \\
(\mu \mathrm{M})\end{array}$ & $\begin{array}{c}K_{\mathrm{d}} \text {, app RRE-Rev } \\
\text { complex }(\mu \mathrm{M})\end{array}$ & $\begin{array}{c}\text { Binding affinity to intended } \\
\text { target }(\mu \mathrm{M})\end{array}$ & $\begin{array}{c}\text { Intended } \\
\text { target }\end{array}$ \\
\hline DPQ & $51 \pm 4$ & $43 \pm 4$ & $140 \pm 55$ & $51 \pm 9$ & IAV promoter \\
Pentamidine & $397 \pm 82$ & $332 \pm 60$ & $>1000$ & $58 \pm 5$ & CUG repeat \\
Yohimbine & $>1000$ & $>1000$ & n.d. & $3900 \pm 1200$ & Ferritin IRE \\
\hline
\end{tabular}

Uncertainty reflects the standard deviation over three independent measurements. When there was no sufficient change in signal to fit a binding curve, the binding constant was not determined (n.d.). Also shown is the binding affinity of each compound to their intended target RNAs reported previously. DPO was determined to have a $K_{d}$ of $51 \mu \mathrm{M}$ to the IAV promoter as measured by an NMR titration (Lee et al. 2014), pentamidine was determined to disrupt the MBNL1-CUG repeat complex with an IC 50 of $58 \mu \mathrm{M}$ as measured by gel shift assay (Warf et al. 2009), and yohimbine was determined to have a $K_{d}$ of 3.9 $\mathrm{mM}$ to the ferritin IRE as measured by a fluorescence-based assay in which the native fluorescence of yohimbine is quenched upon binding to RNA (Tibodeau et al. 2006). 
A

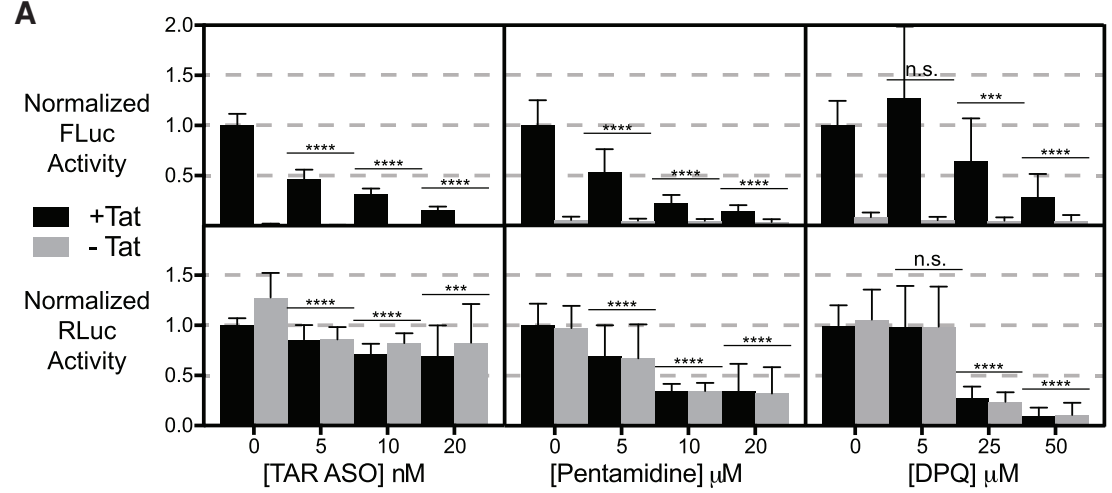

B

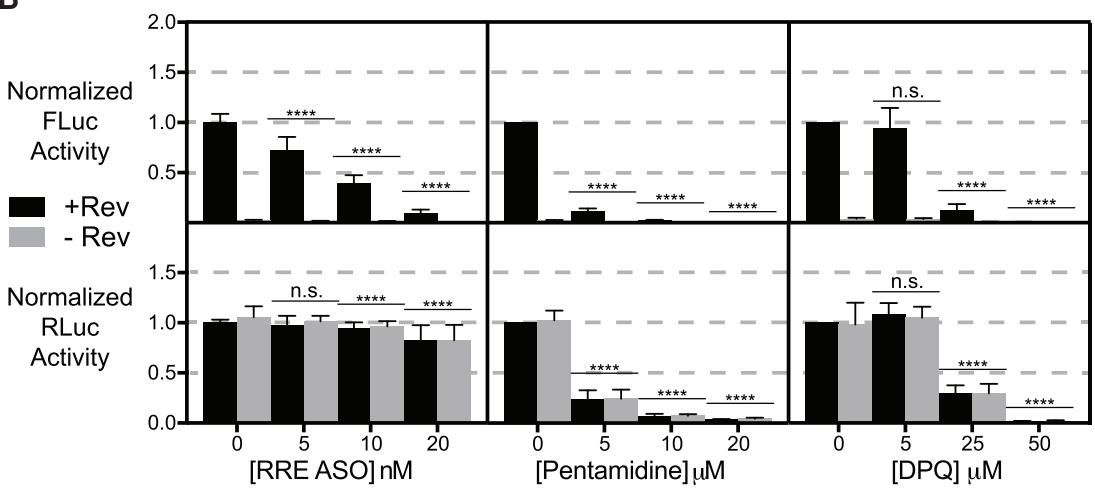

FIGURE 3. Cell-based functional assays for TAR and RRE in the presence of RNA-targeted ASO, Pentamidine, and DPQ. (A) Results for the Tat-dependent transactivation assay. Top panels show FLuc activity, which is dependent on the TAR-Tat interaction. Bottom panels show RLuc activity, which is driven by a CMV promoter and is independent of the TAR-Tat interaction. Black bars indicate the activity in the presence of Tat, gray bars indicate activity in the absence of Tat. (B) Results for the Rev-dependent viral export assay. Top panels show FLuc activity, which is dependent on the RRE-Rev interaction. Bottom panels show RLuc activity, which is driven by a CMV promoter and is independent of the RRE-Rev interaction. Black bars indicate activity in the presence of Rev, gray bars indicate activity in the absence of Rev. $n>5$, with at least three biological replicates. $\left(^{*}\right) P<0.05,\left(^{* *}\right) P<0.01,\left({ }^{* * *}\right) P<0.001$, $(* * * *) P<0.0001$, (n.s.) $=$ no significance.

fluorescence anisotropy by changing the shape of the complex and/or aggregation. Indeed, the compounds did not affect the fluorescence anisotropy of the Rev-ARM peptide in the absence of RRE, which suggests that they are not causing aggregation of the peptide. Yohimbine showed no measurable change in fluorescence anisotropy (Table 1; Supplemental Fig. S4B), which is consistent with the very minor CSPs seen by NMR (Fig. 2B; Supplemental Fig. S1).

We calculated (see Materials and Methods) apparent $\mathrm{K}_{\mathrm{i}} \mathrm{s}$ for all three compounds binding to TAR using the measured $I_{50} s$ for RNA-small molecule binding and the $K_{d} s$ for RNA-peptide binding, (Table 1; Supplemental Fig. S5). For DPQ, the apparent $K_{i} \sim 42 \mu \mathrm{M}$ for TAR binding was comparable to the $K_{\mathrm{d}} \sim 51 \mu \mathrm{M}$ reported for binding to its intended target RNA, the IAV promoter (Lee et al. 2014), while the $K_{\mathrm{d}, \mathrm{app}} \sim 140 \mu \mathrm{M}$ for binding RREIIB was threefold higher. Although different approaches were used to measure the binding affinities and the assays used different conditions, the binding affinity of DPQ for TAR and RREIIB clearly do not differ substantially from its target influenza A promoter.

For pentamidine, the estimated apparent $K_{i} \sim 397 \mu \mathrm{M}$ for TAR binding was sixfold weaker than the $\mathrm{IC}_{50} \sim 58$ $\mu \mathrm{M}$ reported for binding to CUG repeats (Warf et al. 2009), and for RREIIB it could not be reliably determined but we can estimate that $K_{\mathrm{d}, \mathrm{app}}>1000$ $\mu \mathrm{M}$. This suggests some degree of specificity for pentamidine binding to CUG repeats versus TAR and even more so RREIIB. Yohimbine's $K_{i}$ to TAR could not be reliably determined either, but we can estimate that it is also $>1000 \mu \mathrm{M}$, noting that $K_{d}=$ $3900 \mu \mathrm{M}$ for binding to ferritin IRE (Tibodeau et al. 2006). Taken togeth$\mathrm{er}$, these results indicate that these drug-like small molecules can bind to unrelated stem-loop RNAs with comparable affinities.

\section{DPQ and pentamidine inhibit the biological activity of TAR and RRE in cell-based assays}

We examined if the small molecules also inhibited the activity of TAR and RRE in cell-based functional assays (Cullen 1986; Ganser et al. 2020). To assess the effect of the small molecules on the activity of TAR in the cellular context, we transiently transfected HeLa cells with pFLuc-TAR (Ganser et al. 2020) in which TAR drives firefly-luciferase (FLuc) expression, and pcTat (Tiley et al. 1992) and pRLuc (Ganser et al. 2020), which are both driven by the constitutively active cytomegalovirus (CMV) immediate early promoter. When Tat is expressed, it binds TAR and recruits host machinery to form the super elongation complex (SEC), allowing for transactivation of TAR and expression of FLuc. Expression of renilla-luciferase (RLuc) is not Tat-dependent and can be used to assay off-target activity. FLuc expression was also measured in the absence of Tat for every condition as a control for basal transcription. A small molecule specific for TAR is expected to show a decrease in FLuc activity in the presence of Tat, while having little to no effect on RLuc or the level of basal transcription in the absence of Tat.

As a positive control, we treated cells with a locked nucleic acid (LNA) antisense oligonucleotide (ASO) targeted to the bulge and loop region of HIV-1 TAR (Supplemental 
A
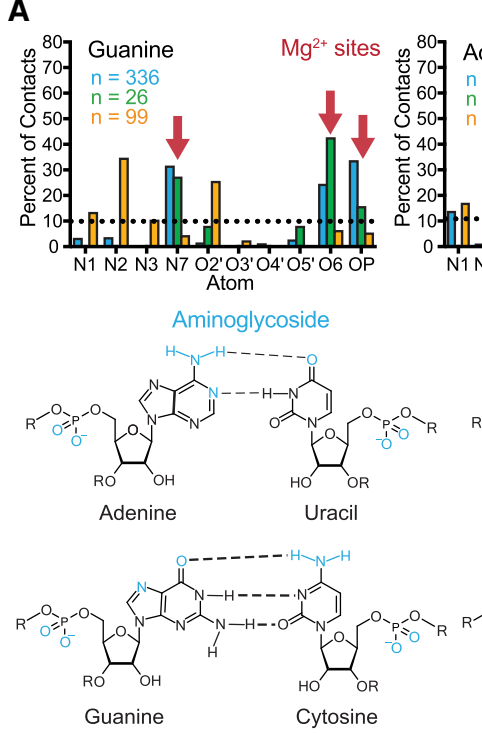
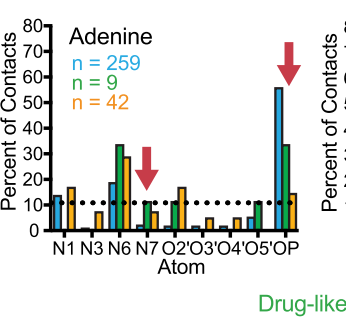

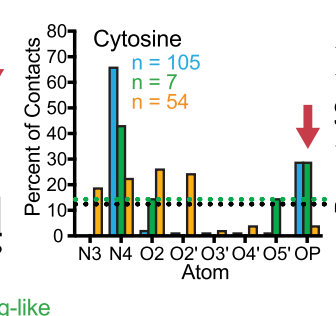

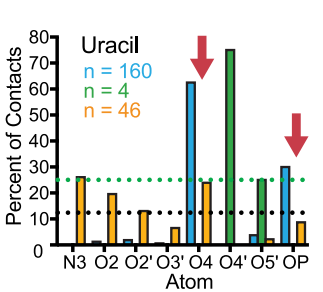

Riboswitch
B

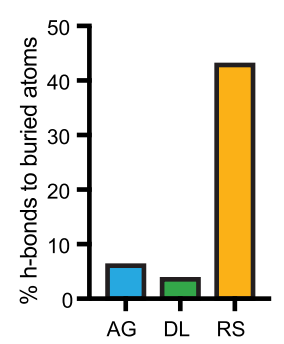

FIGURE 4. Structure-based survey of H-bonding in crystal and NMR structures of RNA-small molecule complexes. The data for aminoglycosideRNA complexes (AG) are in blue, drug-like small molecule-RNA complexes (DL) in green, and small molecule-riboswitch complexes (RS) in orange. ( $A$, top) Column graphs representing the percentage of total $H$-bonds $(n)$ to each nucleotide $(A, U, G$, and $C)$ attributed to different atoms in the nucleotide. RNA atoms that are preferred $\mathrm{Mg}^{2+}$ binding sites (Zheng et al. 2015) are marked by red arrows. The black dotted lines represent expected percentage of $\mathrm{H}$-bond contacts if there is no bias (1 / \# available $\mathrm{H}$-bond donor and $\mathrm{H}$-bond acceptor atoms for each unique nucleotide). Because of the small $\mathrm{H}$-bond sample size ( $n=7$ for cytosine, $n=4$ for uracil) for the drug-like subset, a green dotted line is also shown for uracil and cytosine representing the expected percentage of $\mathrm{H}$-bond contacts if there is no bias for the drug-like group (1/7 for cytosine, 1/4 for uracil). (Bottom) Chemical structure of Watson-Crick base-pairs in which atoms are colored if they exceed the bias threshold. (B) Percentage of $\mathrm{H}$ bond contacts to atoms that are buried in a canonical RNA helix (AN1, AN3, UO2, UO3, GN1, GN2, GN3, CO2, CN3) for each group. (C) Percentage of contacts that pass the bias threshold for which the aminoglycoside group also passes the threshold. This is a measure of the similarity of binding patterns between the drug-like and riboswitch groups to the aminoglycoside group.

Table S2). We observed the expected dose-dependent decrease in FLuc activity with $50 \%$ expression at $\sim 5 \mathrm{nM}$. The effect on RLuc was significantly smaller at all concentrations of the ASO and did not appear to be dose-dependent (Fig. 3A). Previous studies have also shown this type of marginal effect on an independent reporter with a similar sequence TAR-ASO (Turner et al. 2005).

Next we tested the three compounds and found that two of them, DPQ and pentamidine, inhibited transactivation ( $50 \%$ decrease in FLuc activity in the presence of Tat at $\sim 20$ and $\sim 5 \mu \mathrm{M}$, respectively). However, both compounds also had a large, statistically significant dose-dependent effect on RLuc expression, consistent with off-target interactions possibly involving the inhibition of either transcription and/or translation in a TAR independent manner (Fig. 3A). Yohimbine did not show any effect on FLuc or RLuc in this assay, likely because of its low binding affinity for TAR (data not shown).

To deconvolute the contributions of TAR-dependent and TAR-independent drug interactions to the dose-dependent decrease in Fluc observed in the presence of Tat, we also measured the level of FLuc expression in the absence of Tat for each drug dose. The expression of FLuc in the absence of Tat also decreased with increasing drug concentrations; however, a two-way ANOVA analysis indicates that the drug-dependent FLuc decrease in the absence of Tat does not fully explain the FLuc decrease in the presence of Tat (Supplemental Table S2). These results indicate that while much of the inhibitory activity of the small molecule can be attributed to off-target interactions, some inhibition due to interactions between the small molecule and TAR cannot be ruled out.

To assess the effect of these molecules on RRE activity in the cellular context, we cotransfected 293 T cells with the pcRev plasmid (Malim et al. 1988), the pFLuc-RRE plasmid (Ganser et al. 2020), and pRLuc (Ganser et al. 2020). When Rev binds and assembles on RRE, FLuc can be expressed due to Rev-RRE-mediated intron-containing mRNA export. RLuc expression was again used to assay for off-target interactions, and FLuc expression in absence of Rev was measured as a control for basal transcription. We used an RRE-targeted 20-mer LNA ASO as a positive control and observed a dose-dependent effect on viral export with $50 \%$ inhibition in the presence of Rev at $\sim 5-10 \mathrm{nM}$ (Fig. 3B). Again, the ASO had a minor effect on RLuc expression with statistically significant changes only observed at the highest concentrations.

When testing the three experimental compounds in this assay, we found that pentamidine and DPQ had a dosedependent effect on RRE-dependent viral export (50\% 
inhibition observed at $\sim 10-20$ and $\sim 1-5 \mu \mathrm{M}$, respectively). However, once again, the compounds also substantially decreased RLuc activity, indicating off-target interactions (Fig. 3B). We also observed decreased FLuc with increasing drug in the absence of Rev, but twoway ANOVA analysis indicates that the drug-dependent FLuc decrease in the absence of Rev does not fully explain the FLuc decrease in the presence of Rev (Supplemental Table S2). Again, these results indicate that while most of the inhibitory activity of the small molecule can be attributed to off-target interactions, some inhibition due to interactions between the small molecule and RREIIB cannot be ruled out. Taken together, these data reveal that DPQ and pentamidine exhibit low cellular selectivity due to their inhibitory activity against both TAR and RRE in cells, and their dose-dependent effect on RLuc in both assays demonstrates substantial off-target interactions.

\section{High propensity for false positives in cell-based functional assays}

Given that drug-like small molecules have a high propensity to nonspecifically inhibit activity in cell-based functional assays, we surveyed the literature to assess how often specificity controls are performed. We examined all published studies reporting small molecules that bind HIV-1 TAR (Supplemental Table S3) and found that four out of ten studies reporting cell-based functional assays did not measure off-target interactions (Gelus et al. 1999; Hwang et al. 2003; Mischiati et al. 2004; He et al. 2005). Of those six studies that did, $33 \%$ of total compounds tested were found to have significant off-target interactions (Hamy et al. 1998; Mischiati et al. 2001; Murchie et al. 2004). Only one out of the ten studies measured and observed cellular selectivity by performing a cell-based functional assay for an RNA mutant (Stelzer et al. 2011).

One of the drug-like small molecules reported to inhibit TAR-dependent transactivation in a cell-based assay, furamidine, was commercially available. In the original publication (Gelus et al. 1999) this compound was shown to inhibit transactivation in cells with $\mathrm{IC}_{50} \sim 30 \mu \mathrm{M}$; however, measurements of off-target interactions were not performed. Additionally, furamidine had been shown in a previous study to bind RREIIB in vitro (Ratmeyer et al. 1996), indicating it may have nonspecific binding capacity and its activity in the transactivation assay may not be fully due to TARbinding.

We tested furamidine in our cell-based Tat-dependent transactivation assay as described above. We found that furamidine, like pentamidine and DPQ, had a large dose dependent effect on both FLuc and RLuc (50\% inhibition of FLuc $\sim 20 \mu \mathrm{M}$ ), indicating that it also has abundant offtarget effects that were not previously assessed (Supplemental Fig. S6). These results indicate that when the activity of the small molecule on the assay in the absence of the RNA of interest is not measured, many small molecules reported to inhibit RNA activity in cells may do so via off-target interactions that are unrelated to binding a target RNA.

\section{Drug-like molecules preferentially hydrogen bond to exposed sites in canonical stem-loop RNAs}

Structural studies of DPQ bound to RNA (Lee et al. 2014) and of pentamidine bound to DNA (Edwards et al. 1992) show that they form $\mathrm{H}$-bonds with functional groups in and around bulges, stems, internal loops, and mismatches. These include $\mathrm{H}$-bonds between the methoxy oxygens of DPQ and the AUA internal loop of the IAV promotor, as well as the cytosine-N4 of the junctional G-C base pair (bp), and between the primary amine of pentamidine and adenine ribose-O4'. Such $\mathrm{H}$-bond contacts to sites commonly exposed and available for interaction in generic stem-loop RNAs composed of Watson-Crick bps, including TAR and RREIIB, along with electrostatic interactions (Hermann and Westhof 1999; Walter et al. 1999), could provide a basis for nonspecific binding to RNAs by these drug-like molecules.

To test this hypothesis, we surveyed X-ray and NMR structures of stem-loop RNAs bound to drug-like small molecules (Davis et al. 2004; Dibrov et al. 2012; Lee et al. 2014) and enumerated all of the H-bonds between the small molecule and the RNA. While our analysis was focused on counting the number of $\mathrm{H}$-bonds, the $\mathrm{H}$-bonds can vary in strength. Future studies are needed to both characterize $\mathrm{H}$-bond strength and deconvolute contributions from electrostatics to binding at each site. As a negative control, we also surveyed the crystal structures of riboswitches (Schwalbe et al. 2007; McCown et al. 2017), which contain higher-order structural motifs and have evolved to bind metabolites with high selectivity. As a positive control, we surveyed the structures of RNAs bound to aminoglycosides (Faber et al. 2000; François et al. 2005; Han et al. 2005; Kondo et al. 2007; Freisz et al. 2008), which are well known to bind RNAs nonspecifically (Fig. 4; Supplemental Table S4). It is interesting to note that there were not nearly as many drug-like small molecule-bound RNA structures $(n=17)$ available as there were riboswitch $(n=27)$ and aminoglycoside-RNA structures $(n=60)$.

For aminoglycosides, $294 \%$ of the $\mathrm{H}$-bonds are with donor and acceptor atoms that are solvent exposed and accessible even in Watson-Crick bps (Fig. 4A,B), such as atoms in the phosphate backbone $\left(\mathrm{OP}, \mathrm{O5}^{\prime}\right)$, ribose moiety $\left(\mathrm{O} 2^{\prime}, \mathrm{O}^{\prime}, \mathrm{O}^{\prime}\right)$, and Hoogsteen face (N7, N4, O4) of the nucleobase (Walter et al. 1999). Guanine-N7, guanineO6, uracil-O4, cytosine-N4, adenine-N6, and the phosphate oxygens (OP) for all bases are the positions most frequently involved in $\mathrm{H}$-bonding (Fig. 4A). This pattern 
overlaps considerably with the preferred sites for $\mathrm{Mg}^{2+}$ association (Ennifar et al. 1999; Zheng et al. 2015), which include OP for all bases, guanine-N7, adenine-N7, uracilO4, and guanine-O6 (Fig. 4A).

In stark contrast, the $\mathrm{H}$-bonds present in riboswitchligand complexes are biased toward atoms residing in the Watson-Crick base-pairing face of the nucleobase. Approximately $43 \%$ of $\mathrm{H}$-bonds were to RNA atoms that would otherwise be buried and inaccessible in a canonical RNA helix, such as guanine-N1, guanine-N2, cytosine-N1, cytosine-O2, and uracil-N3 (Fig. 4A,B). While we do not know whether metabolites can also form $\mathrm{H}$-bonds with exposed atoms in Watson-Crick bps, nature has clearly evolved more complex binding pockets, which enable more specific ligand recognition (Schwalbe et al. 2007; McCown et al. 2017). One exception is the ribose $2^{\prime}-\mathrm{OH}$ group, which is highly represented riboswitch $\mathrm{H}$-bonds.

Interestingly, we find that the drug-like small molecules, including DPQ, predominately model the behavior of aminoglycosides (Fig. 4C). 96\% of $\mathrm{H}$-bond contacts in the group of drug-like small molecules are formed with atoms that are solvent accessible in the canonical Watson-Crick bp helical structure (Fig. 4A,B), including guanine-N7 and the phosphate backbone (OP1 and OP2). Moreover, approximately $87 \%$ of the RNA sites of $\mathrm{H}$-bonding overlap with those seen with aminoglycosides (Fig. 4C). This is in contrast with only $28 \%$ of riboswitch $\mathrm{H}$-bonding sites overlapping with those observed with aminoglycosides (Fig. 4C). However, a notable departure from this behavior includes a slight bias toward $\mathrm{H}$-bonding with ribose oxygens $\left(\mathrm{O} 2^{\prime}, \mathrm{O}^{\prime}, \mathrm{O} 5^{\prime}\right)$, similar to the riboswitch structures (Fig. 4A). This slight shift from binding to ribose oxygens versus phosphate oxygens may be due to the fact that these drug-like molecules have a near-neutral charge, unlike aminoglycosides in which the positive charge may bias $\mathrm{H}$-bonding to the phosphate backbone. Therefore, the ability to form $\mathrm{H}$-bonds with functional groups commonly presented in stem-loop RNAs, along with contributions from electrostatic interactions, provides a plausible mechanism for nonspecific binding of drug-like small molecules to stem-loop RNAs.

\section{DISCUSSION}

In concordance with observations from previous studies (Mischiati et al. 2001; Murchie et al. 2004; Nahar et al. 2014; Schmidt 2014), our results extend the group of nonselective RNA binders beyond aminoglycosides and intercalators to encompass near-neutral, nonplanar, drug-like compounds when binding to stem-loop RNAs. These molecules likely bind RNAs nonspecifically by $\mathrm{H}$-bonding to exposed functional groups in and around canonical RNA motifs such as bulges and internal loops as well as through electrostatic interactions between negatively charged pockets on the RNA formed by backbone phosphate groups as well as other sugar/base electronegative groups and cationic groups on the small molecule. Additional studies are needed to assess the relative contributions of $\mathrm{H}$-bonding and other electrostatic interactions to nonspecific binding.

The likelihood for nonspecific binding to structurally simple stem-loop RNAs is expected to be particularly high for low molecular weight compounds because they can only form a limited number of $\mathrm{H}$-bonds that provide little discrimination against different but structurally related RNAs. Riboswitch ligands are also low molecular weight, but the RNA provides many unique binding motifs and geometries that increase the likelihood of specific binding. Indeed, work targeting CUG repeats and microRNAs (Velagapudi et al. 2014; Rzuczek et al. 2017) has shown that increased specificity toward stem-loop RNAs can be achieved with higher molecular weight compounds that increase the number of $\mathrm{H}$-bonds. Thus, by increasing the $\mathrm{H}$-bonding binding footprint and tailoring it to a target RNA, it is feasible to increase binding specificity to stem-loop RNAs.

Experiments that assess off-target interactions and RNA selectivity are clearly important when it comes to testing novel RNA-binders in vitro and in vivo (Costales et al. 2017; Donlic et al. 2018; Naro et al. 2018; Abulwerdi et al. 2019; Zhang et al. 2020). Furthermore, selective binding in vitro does not imply selective binding in the cellular context where many other structurally similar RNAs are likely present, and target RNAs may be bound by proteins. Experiments that appropriately assess target engagement and functional selectivity in the cell should be consistently performed when reporting novel RNA-targeted small molecules. However, our survey of the HIV-1 TAR literature (Supplemental Table S3) revealed that these controls are not always performed (Gelus et al. 1999; Hwang et al. 2003; He et al. 2005). In fact, based on our survey of HIV-1 TAR studies, only six out of ten studies measured off-target interactions when reporting compounds with cell-activity, and those that did found 33\% of the compounds to have promiscuous binding (Hamy et al. 1998; Mischiati et al. 2001; Murchie et al. 2004). Beyond TAR, studies of microRNA-targeted small molecules have shown that when off-target effects are assessed, many molecules have broad, promiscuous activity (Nahar et al. 2014; Schmidt 2014) and/or interact with assay reporter proteins (Thorne et al. 2010). Given the high tendency of drug-like small molecules with favorable $\mathrm{H}$-bonding capacity to bind a variety of RNAs and to even have apparent cellular activity, controls that test off-target interactions and cellular specificity are of paramount importance. Future studies could also use recently developed approaches to more directly assess target engagement and selectivity in cells (Rzuczek et al. 2017; Shin et al. 2017). 


\section{MATERIALS AND METHODS}

\section{RNA sample preparation}

${ }^{13} \mathrm{C} /{ }^{15} \mathrm{~N}$ labeled HIV1-TAR and RREIIB for NMR studies was prepared by in vitro transcription using a DNA template containing the T7 promoter (Integrated DNA Technologies). The DNA template was annealed at $50 \mu \mathrm{M}$ DNA in the presence of $3 \mathrm{mM}$ $\mathrm{MgCl}_{2}$ by heating to $95^{\circ} \mathrm{C}$ for $5 \mathrm{~min}$ and cooling on ice for $1 \mathrm{~h}$. The transcription reaction was carried out at $37^{\circ} \mathrm{C}$ for $12 \mathrm{~h}$ with T7 polymerase (New England Biolabs) in the presence of ${ }^{13} \mathrm{C} /{ }^{15} \mathrm{~N}$ labeled nucleotide triphosphates (Cambridge Isotope Laboratories, Inc.). Unlabeled HIV1-TAR and RREIIB for in vitro displacement assays was synthesized with the MerMade 6 DNA/RNA synthesizer (Bioautomation) using standard phosphoramidite chemistry and 2'-hydroxyl deprotection protocols. Both labeled and unlabeled samples were purified using the same methodology, using 20\% (w/v) denaturing PAGE with $8 \mathrm{M}$ urea and $1 \times$ TBE. RNA was excised and then electroeluted (Whatman, GE Healthcare) in $1 \times$ TAE buffer. Eluted RNA was then concentrated and ethanol precipitated. RNA was then dissolved in water to a concentration of $\sim 50 \mu \mathrm{M}$ and annealed by heating at $95^{\circ} \mathrm{C}$ for $5 \mathrm{~min}$ and cooling on ice for $1 \mathrm{~h}$. For NMR experiments, ${ }^{13} \mathrm{C} /{ }^{15} \mathrm{~N}$ labeled RNA was buffer exchanged using centrifugal concentration ( $3 \mathrm{kDa}$ molecular weight cutoff, EMD Millipore) into NMR buffer (15 mM NaH $\mathrm{PO}_{4} / \mathrm{Na}_{2} \mathrm{HPO}_{4}, 25 \mathrm{mM}$ $\mathrm{NaCl}, 0.1 \mathrm{mM}$ EDTA, $10 \%$ (v/v) $\mathrm{D}_{2} \mathrm{O}$ at $\mathrm{pH}$ 6.4). For in vitro assays, unlabeled TAR RNA was diluted to $150 \mathrm{nM}$ in Tris-HCl assay buffer (50 mM Tris- $\mathrm{HCl}, 50 \mathrm{mM} \mathrm{KCl}, 0.01 \%$ (v/v) Triton X-100 at pH 7.4), and unlabeled RRE RNA was diluted to $180 \mathrm{nM}$ in reaction buffer (30 $\mathrm{mM}$ HEPES $\mathrm{pH}=7.0,100 \mathrm{mM} \mathrm{KCl}, 10 \mathrm{mM}$ sodium phosphate, $10 \mathrm{mM}$ ammonium acetate, $10 \mathrm{mM}$ guanidinium chloride, $2 \mathrm{mM}$ $\mathrm{MgCl}_{2}, 20 \mathrm{mM} \mathrm{NaCl}, 0.5 \mathrm{mM}$ EDTA, and $0.001 \%$ (v/v) Triton$\mathrm{X} 100)$.

\section{Small molecule and antisense oligonucleotide (ASO) preparation}

Small molecules were ordered in powder format from MilliporeSigma: DPQ (6,7-dimethoxy-2-(1-piperazinyl)-4-quinazolinamine) \#R733466; Pentamidine isethionate salt \#P0547; Yohimbine \#49768. Pentamidine and yohimbine were dissolved in water to $20 \mathrm{mM}$ stocks. DPQ was dissolved in dimethyl sulfoxide (DMSO) to a $20 \mathrm{mM}$ stock. Locked nucleic acid (LNA) ASOs were ordered from Qiagen and dissolved in water to $100 \mu \mathrm{M}$. The TAR (16mer) sequence was $5^{\prime}+C^{*}+T^{*}+C^{*} C^{*} C m^{*} A^{*} G^{*}$ $G^{*} C^{*} T^{*} C^{*} A^{*} G^{*}+A^{*}+T^{*}+C 3^{\prime}$ while RRE (20mer) was $5^{\prime}+G^{*}+G^{*}$ $+C^{*}+C^{*}+T^{*} G^{*} T^{*} A^{*} C^{*} C^{*} G^{*} T^{*} C^{*} A^{*} G^{*}+C^{*}+G^{*}+T^{*}+C^{*}+A \quad 3^{\prime}$, in which $(+),\left(^{*}\right)$, and $(\mathrm{Cm})$ indicate LNA, phosphorothioate linkage, and cytosine base with a 2'O-methyl modification, respectively. Marvin was used for drawing, displaying, and characterizing small molecule chemical structures, Marvin 19.21.0, Chemaxon (https ://www.chemaxon.com).

\section{NMR experiments}

All NMR experiments were performed at $25^{\circ} \mathrm{C}$ on a Bruker 600 $\mathrm{MHz}$ spectrometer equipped with triple resonance $\mathrm{HCN}$ cryogenic probes. ${ }^{13} \mathrm{C} /{ }^{15} \mathrm{~N}$ labeled RNA was exchanged into NMR buffer
(15 mM NaH ${ }_{2} \mathrm{PO}_{4} / \mathrm{Na}_{2} \mathrm{HPO}_{4}, 25 \mathrm{mM} \mathrm{NaCl}, 0.1 \mathrm{mM}$ EDTA, $10 \%(\mathrm{v} / \mathrm{v}) \mathrm{D}_{2} \mathrm{O}$ at $\mathrm{pH}$ 6.4). For spectra in the presence of magnesium, $\mathrm{Mg}^{2+}$ was added directly to the sample to a final concentration of $3 \mathrm{mM}$. NMR spectra were processed with NMRPipe (Delaglio et al. 1995) and visualized with SPARKY (Goddard and Kneller 2006). All molecules were soluble in water except DPQ, which was dissolved in DMSO. NMR spectra for free and small molecule bound RNAs were recorded in 2\% DMSO for the DPQ panels in Figure 2, and Supplemental Figures S1 and S2. NMR samples were prepared by mixing the RNA $(50 \mu \mathrm{M})$ with small molecules (DPQ and pentamidine) at a 1:4 molar ratio. A molar ratio of 1:60 was used for yohimbine to observe the CSPs shown in Figure 2 and Supplemental Figures S1 and S2 consistent with its lower affinity to its target RNA (Tibodeau et al. 2006). This titration is shown in Supplemental Figure S3.

\section{Fluorescence-based TAR-Tat displacement assay}

The fluorescence-based displacement assay used a peptide mimic of Tat containing an arginine rich motif (ARM), an amino-terminal fluorescein label, and a carboxy-terminal TAMRA label $(\mathrm{N}$ AAARKKRRQRRR-C, Genscript), and MerMade-synthesized unlabeled HIV-1 TAR. The peptide is highly flexible when free in solution, allowing the two terminal fluorophores to interact and quench the fluorescent signal (Matsumoto et al. 2000). However, upon binding to TAR the peptide becomes structured and the two fluorophores are held apart, allowing fluorescence resonance energy transfer from fluorescein to TAMRA. Thus, when a small molecule displaces the peptide, the fluorescence signal decreases. For this assay we used a concentration of 50 $\mathrm{nM}$ TAR and $20 \mathrm{nM}$ Tat-ARM peptide because this ratio gave the maximum fluorescence signal. TAR and Tat-ARM peptide were incubated with serial dilutions of the small molecules in a 384-well plate for $10 \mathrm{~min}$. The assay buffer consisted of $50 \mathrm{mM}$ Tris- $\mathrm{HCl}, 50 \mathrm{mM} \mathrm{KCl}, 0.01 \%$ (v/v) Triton X-100 at $\mathrm{pH} 7.4$. Fluorescence was then measured in triplicate using a CLARIOstar plate reader (BMG Labtech) with a $485 \mathrm{~nm}$ excitation wavelength and $590 \mathrm{~nm}$ emission wavelength. The fluorescence data were fit using a four parameter variable slope dose-response model using GraphPad Prism version 8.4.1 for Mac (GraphPad Software, Inc.) and Equation 1:

$$
A=\frac{A_{\text {free }}+\left(A_{\text {bound }}-A_{\text {free }}\right)}{1+10^{\left(\log \left(I C_{50}\right)-X\right)(Y)}},
$$

where $A$ is the measured fluorescence at a given small molecule concentration $(X)$; $A_{\text {free }}$ is the measured fluorescence in the absence of TAR; $A_{\text {bound }}$ is the fluorescence with saturated TAR-Tat binding; and $Y$ is the Hill Slope. This assay was repeated three times, the average and standard deviation of the resulting $50 \%$ inhibitory constants $\left(\mathrm{IC}_{50}\right)$ are reported in Table 1 and Supplemental Figure S4A.

$I C_{50}$ values were converted to apparent $K_{i}$ s using the ChengPrusoff equation:

$$
K_{i}=\frac{I_{50}}{1+\left(\frac{[L]}{K_{d}}\right)^{\prime}},
$$

where $K_{i}$ is the inhibition constant of the small molecule bound to TAR (Table 1); $L$ is the constant concentration of Tat-ARM peptide 
used in determining the direct TAR-Tat $K_{d}(20 \mathrm{nM}) ; K_{d}$ is the binding constant between TAR and the Tat-ARM peptide (103.1 nM, Supplemental Fig. S5).

\section{Fluorescence-based RREIIB-Rev displacement assay}

Fluorescence polarization displacement assays were carried out using 3'-end fluorescein labeled Rev-ARM peptide (Rev-Fl, TRQARRNRRRRWRERQRAAAACK-FITC, LifeTein LLC) (Chu et al. 2019). The serially diluted small molecule drugs in the reaction buffer (30 mM HEPES pH =7.0, $100 \mathrm{mM} \mathrm{KCl,} 10 \mathrm{mM}$ sodium phosphate, $10 \mathrm{mM}$ ammonium acetate, $10 \mathrm{mM}$ guanidinium chloride, $2 \mathrm{mM} \mathrm{MgCl}_{2}, 20 \mathrm{mM} \mathrm{NaCl}, 0.5 \mathrm{mM}$ EDTA, and $0.001 \%(\mathrm{v} / \mathrm{v})$ Triton-X100) was incrementally added into a 384-well plate containing $10 \mathrm{nM}$ Rev-Fl with or without $60 \mathrm{nM}$ RREIIB (Prado et al. 2016; Chu et al. 2019). Fluorescence polarization (FP) was measured in triplicate using a CLARIOstar plate reader (BMG LABTECH) using $480 \mathrm{~nm}$ excitation and a $540 \mathrm{~nm}$ emission filter (Prado et al. 2016; Chu et al. 2019). This assay was repeated three times, the average and standard deviation of the resulting $K_{d \text {,app }}$ values are reported in Table 1 and Supplemental Figure S4B. These are $K_{d, \text { app }}$ and not $I C_{50}$ values because an increase in FP was observed, representing direct binding to the RREIIB-Rev peptide complex and not peptide displacement. The $I C_{50}$ values were also fitted with the three-parameter dose-response model in GraphPad Prism version 8.4.1 for Mac (GraphPad Software, Inc.) using Equation 3:

$$
A=\frac{A_{\text {free }}+\left(A_{\text {bound }}-A_{\text {free }}\right)}{1+10^{X-\log \left(I C_{50}\right)}}
$$

where $A$ is the measured FP; $A_{\text {free }}$ is the FP without Rev-Fl binding; $A_{\text {bound }}$ is the FP with saturated Rev-Fl binding; $X$ is the total small molecule concentration. $K_{d, a p p}$ values were not converted to $K_{i} s$ because displacement of the peptide was not observed in the assay.

\section{TAR-Tat peptide binding assay}

The fluorescence-based TAR-Tat peptide binding assay uses the same peptide and TAR construct as the displacement assay. In this assay a constant concentration of $20 \mathrm{nM}$ Tat peptide is plated with serial dilutions of TAR in a 384-well plate. Both TAR and Tat peptide were diluted in assay buffer consisting of $50 \mathrm{mM} \mathrm{Tris-} \mathrm{HCl}$, $100 \mathrm{mM} \mathrm{NaCl}, 0.01 \%$ (v/v) Triton X-100 at pH 7.4. Fluorescence was then measured in triplicate with a CLARIOstar plate reader (BMG Labtech) with a $485 \mathrm{~nm}$ excitation wavelength and 590 $\mathrm{nm}$ emission wavelength. This assay was repeated three times, the average and standard deviation of the $K_{d}$ is reported in Supplemental Figure S6. Binding curves were fit to Equation 4 in GraphPad Prism version 8.4.1 for Mac (GraphPad Software, Inc.) to determine the $K_{d}$ :

$A=A_{\text {free }}+\left(A_{\text {bound }}-A_{\text {free }}\right)\left(\frac{[\text { TAR }]+[\text { Tat }]+K_{d}-\sqrt{\left([T A R]+[\text { Tat }]+K_{d}\right)^{2}-4[\text { TAR }][\text { Tat }]}}{2[\text { TAR }]}\right)$

where $A$ is the measured fluorescence; $A_{\text {free }}$ is the fluorescence in the absence of TAR-Tat binding; $A_{\text {bound }}$ is the fluorescence at saturated TAR-Tat binding; $K_{d}$ is the measured apparent binding af- finity and [TAR] and [Tat] are the concentrations of TAR and the Tat peptide, respectively.

\section{TAR-Tat dependent transactivation assay}

pcTat (Tiley et al. 1992), pFLuc-TAR (Ganser et al. 2020), pcRLuc (Ganser et al. 2020), and pBC12-CMV (Tiley et al. 1992) expression plasmids were constructed as described previously. HeLa cells were maintained in Dulbecco's modified Eagle medium (DMEM) supplemented with $10 \%$ fetal bovine serum and $0.1 \%$ gentamicin at $37^{\circ} \mathrm{C}$ and $5 \% \mathrm{CO}_{2}$. Cells were plated to $1.5 \times 10^{5}$ cells per well in 24-well plates, and treated with small molecule drug or vehicle only, $24 \mathrm{~h}$ prior to transfection with polyethylenimine PEI (Polysciences). The primary transfection mixtures contained $250 \mathrm{ng}$ pFLuc-TAR reporter plasmid, 10 ng RLuc control plasmid, \pm 20 ng pcTat expression plasmid, and pBC12-CMV filler DNA plasmid up to a total of $1510 \mathrm{ng}$ total DNA per well. ASOtreated cells were transfected with ASO using PEI 10 min after transfection with the primary mixture. Media with drug or vehicle was replaced at $24 \mathrm{~h}$ post-transfection, and cells were lysed at $4 \mathrm{~h}$ post-transfection with $250 \mu \mathrm{L}$ passive lysis buffer (Promega) and incubated $20 \mathrm{~min}$ at room temperature. FLuc and RLuc activity was measured using a Dual-Luciferase Reporter Assay System (Promega).

\section{RRE-Rev dependent export assay}

pcRev (Malim et al. 1988), pFLuc-RRE (Ganser et al. 2020), pRLuc (Ganser et al. 2020), and pBC12-CMV (Tiley et al. 1992) expression plasmids were constructed as described previously. $293 \mathrm{~T}$ cells were maintained in Dulbecco's modified Eagle medium (DMEM) supplemented with $10 \%$ fetal bovine serum and $0.1 \%$ gentamicin at $37^{\circ} \mathrm{C}$ and $5 \% \mathrm{CO}_{2}$. Cells were plated to $1 \times 10^{5}$ cells per well in 24-well plates, and treated with small molecule drug or vehicle only, $24 \mathrm{~h}$ prior to transfection with PEl. The primary transfection mixtures contained $5 \mathrm{ng}$ pFLuc-RRE reporter plasmid, $5 \mathrm{ng}$ RLuc control plasmid, 1 ng pcRev expression plasmid, and pBC12-CMV filler DNA plasmid up to a total of $1010 \mathrm{ng}$ total DNA per well. ASO-treated cells were transfected with ASO using PEI 10 min after transfection with the primary mixture. Media with drug or vehicle was replaced at $24 \mathrm{~h}$ post-transfection, and cells were lysed at $4 \mathrm{~h}$ post-transfection with $250 \mu \mathrm{L}$ passive lysis buffer (Promega) and incubated $20 \mathrm{~min}$ at room temperature. FLuc and RLuc activity was measured using a Dual-Luciferase Reporter Assay System (Promega).

\section{Statistical analysis}

Statistical analysis was done using the program JMP (JMP Pro, Version 14, SAS Institute Inc., 1989-2019). For both the TAR-Tat dependent transactivation assay and the RRE-Rev dependent export assay, the raw luminescence values of each condition in each experiment were normalized to the average of the vehicle-treated, +Tat control luminescence values of that experiment. $n=$ at least six replicates for each treatment group, with at least three being biological replicates. For each concentration of the small molecule or $\mathrm{ASO}$, the + and -Tat conditions were compared to the + and - Tat conditions of the vehicle treated control in a 
two-way ANOVA. The statistical significance of the main effect of the treatment on both the + and -Tat conditions are shown as asterisks above each condition in Figure $4 .{ }^{*} P<0.05,{ }^{* *} P<0.01$, ${ }^{* * *}$ $P<0.001,{ }^{* * * *} P<0.0001$, n.s. $=$ no significance. The $P$-values of the interaction effect between Tat and drug are shown in Supplemental Table S2.

\section{TAR-binding small molecule literature survey and analysis}

We surveyed studies that reported on small molecules binding to TAR published between 199 and 2020. From 1995-2014, we used the TAR-binding small molecule studies previously reported in Ganser et al. (2018). For the studies from 2014-2019, we performed a PubMed and Google Scholar search using the terms HIV AND TAR AND RNA AND binding with a 2014-2019 date filter. From the search results, we included all studies reported small molecules (not proteins or peptide mimetics) binding to TAR in vitro with a measurable $I_{50}$. We redid the search replacing the word "binding" with "inhibit" and added any additional studies that fulfilled our criteria that were not included in the first search. There are 47 primary scientific articles included; however, two of them we have classified into one study, as one article reported on in vitro and some cell-based experiments and a later article by the same authors included additional cell-based and viral studies of the same compounds (Mei et al. 1997, 1998). In total there are 46 studies, and they are enumerated in Supplemental Table S3. At the in vitro level we describe the assays used to measure affinity and any tests of RNA selectivity that were performed. At the cell based and viral assay levels we describe the experiments performed in each study as well as any tests of off-target interactions, RNA selectivity, cell viability, and list the cell lines and viral strains used.

\section{Structure survey and analysis}

This survey was conducted using the RCSB Protein Data Bank (PDB) in August of 2017 (Berman et al. 2000, 2007). We first constructed a master-database of all nonredundant RNA-ligand complexes (Supplemental Table S4). The PDB was filtered to only include structures that contain RNA, at least one ligand, and do not contain DNA or protein. A total of 623 X-ray and 58 NMR solution structures satisfying the above criteria were downloaded from the PDB website (https://www.rcsb.org). This set of structures was filtered to exclude structures in which the only type of small molecule ligand is an ion, a solvent molecule, or a linker molecule typically used to improve crystallization conditions. This reduced the data set to 288 crystal structures and 48 NMR solution structures. This set of structures were filtered to exclude redundant structures that may bias the data set. For any clusters of structures with global RMSDs $<2 \AA$ (often the same RNA-drug pair), we included only one parent structure from that cluster. All RNA-ligand intermolecular $\mathrm{H}$-bonds were identified for each structure using X3DNA-DSSR (Lu et al. 2015). We removed any PDB structures that did not include any $\mathrm{H}$-bonds (complex formed entirely by stacking interactions).

We then refined the $\mathrm{H}$-bonding criteria for our master-database. X3DNA-DSSR has a very large range of distances between donor and acceptor atoms ( $4 \AA$ and below), and so we applied ad- ditional distance criteria (between $2.0 \AA$ and $3.5 \AA$ ) to more rigorously define $\mathrm{H}$-bonds. To remove any additional sources of overrepresentation bias in the data set, we removed all $\mathrm{H}$-bonds that were redundant due to multiple identical bioassemblies within a single structure. All remaining $\mathrm{H}$-bonds were then manually inspected to remove obvious false positive $\mathrm{H}$-bonds such as donor-donor and acceptor-acceptor pairs, even considering potential tautomerizations. The resulting master-database includes a final set of 223 unique PBD structures (185 crystal and $38 \mathrm{NMR}$ ), comprised of 2168 unique $\mathrm{H}$-bonds in total (Supplemental Table S4).

We then refined this master-database to a specific subset for the purposes of this study, the data shown in Figure 4. First, we classified the PDB structures into three subgroups: (i) stem-loop RNAs bound to aminoglycosides- 55 structures; (ii) riboswitches bound to their native ligand-27 structures; (iii) stem-loop RNAs bound to drug-like small molecules-17 structures for a total of 99 structures (71 crystal, 28 NMR) (Supplemental Table S5). Any PDB structures that did not fit into one of these three categories, such as synthetic aptamers with tertiary structure and complexes in which the small molecules are nucleotides that exhibit WatsonCrick base-pairing with the RNA to form a canonical helix, were excluded from this study. We then further refined the $\mathrm{H}$-bonds in this subset of PDB structures. Any $\mathrm{H}$-bonds to noncanonical (modified) RNA bases were excluded from analysis. Any palindromic RNA-small molecule interactions in a single structure were marked such that only a single copy of each unique $\mathrm{H}$ bond was included in the analysis. These exclusions left a total of $1147 \mathrm{H}$-bonds from the 99 structures of this subset to be analyzed. The number of ligand $\mathrm{H}$-bond contacts to each unique $\mathrm{H}$ bond donor/acceptor RNA atom was then determined for each of the three PDB subgroups (aminoglycoside, drug-like, riboswitch) (Fig. 4).

\section{SUPPLEMENTAL MATERIAL}

Supplemental material is available for this article.

\section{ACKNOWLEDGMENTS}

We would like to thank the Duke Magnetic Resonance Spectroscopy Center for nuclear magnetic resonance resources. We would also like to thank Dr. Christopher Holley for helpful guidance on antisense oligonucleotide design and implementation, and Atul Rangadurai for critical reading of the manuscript. This work was supported by the National Institutes of Health $(\mathrm{NIH}) /$ National Institute of Allergy and Infectious Diseases (NIAID) grants U54 Al150470 to H.M.A.-H. and F30 Al14328201A1 to M.L.K.

Received May 2, 2020; accepted September 26, 2020.

\section{REFERENCES}

Abulwerdi FA, Xu W, Ageeli AA, Yonkunas MJ, Arun G, Nam H, Schneekloth JS, Dayie TK, Spector D, Baird N, et al. 2019. Selective small-molecule targeting of a triple helix encoded by the long noncoding RNA, MALAT1. ACS Chem Biol 14: 223225. doi:10.1021/acschembio.8b00807 
Bardaro MF, Shajani Z, Patora-Komisarska K, Robinson JA, Varani G. 2009. How binding of small molecule and peptide ligands to HIV-1 TAR alters the RNA motional landscape. Nucleic Acids Res 37: 1529-1540. doi:10.1093/nar/gkn1074

Berman HM, Bhat TN, Bourne PE, Feng Z, Gilliland G, Weissig H, Westbrook J. 2000. The Protein Data Bank and the challenge of structural genomics. Nat Struct Biol 7: 957-959. doi:10.1038/ 80734

Berman H, Henrick K, Nakamura H, Markley JL. 2007. The worldwide Protein Data Bank (wwPDB): ensuring a single, uniform archive of PDB data. Nucleic Acids Res 35: D301-D303. doi:10.1093/ nar/gkl971

Bevilacqua PC, Ritchey LE, Su Z, Assmann SM. 2016. Genome-wide analysis of RNA secondary structure. Annu Rev Genet 50: 235266. doi:10.1146/annurev-genet-120215-035034

Bickerton GR, Paolini G V., Besnard J, Muresan S, Hopkins AL. 2012. Quantifying the chemical beauty of drugs. Nat Chem 4: 90-98. doi:10.1038/nchem.1243

Callejo A, Sedó-Cabezón L, Juan ID, Llorens J. 2015. Cisplatin-induced ototoxicity: effects, mechanisms and protection strategies. Toxics 3: 268-293. doi:10.3390/toxics3030268

Chang DD, Sharp PA. 1989. Regulation by HIV Rev depends upon recognition of splice sites. Cell 59: 789-795. doi:10.1016/0092-8674 (89)90602-8

Chi X, Gatti P, Papoian T. 2017. Safety of antisense oligonucleotide and siRNA-based therapeutics. Drug Discov Today 22: 823-833. doi:10.1016/j.drudis.2017.01.013

Childs-Disney JL, Disney MD. 2016. Approaches to validate and manipulate RNA targets with small molecules in cells. Annu Rev Pharmacol Toxicol 56: 123-140. doi:10.1146/annurev-pharmtox010715-103910

Chu CC, Plangger R, Kreutz C, Al-Hashimi HM. 2019. Dynamic ensemble of HIV-1 RRE stem IIB reveals non-native conformations that disrupt the Rev-binding site. Nucleic Acids Res 47: 7105-7117. doi:10.1093/nar/gkz498

Connelly CM, Moon MH, Schneekloth JS. 2016. The emerging role of RNA as a therapeutic target for small molecules. Cell Chem Biol 23: 1077-1090. doi:10.1016/j.chembiol.2016.05.021

Coonrod LA, Nakamori M, Wang W, Carrell S, Hilton CL, Bodner MJ, Siboni RB, Docter AG, Haley MM, Thornton CA, et al. 2013. Reducing levels of toxic RNA with small molecules. ACS Chem Biol 8: 2528-2537. doi:10.1021/cb400431f

Corey DR. 2017. Nusinersen, an antisense oligonucleotide drug for spinal muscular atrophy. Nat Neurosci 20: 497-499. doi:10 $.1038 / \mathrm{nn} .4508$

Costales MG, Haga CL, Velagapudi SP, Childs-Disney JL, Phinney DG, Disney MD. 2017. Small molecule inhibition of microRNA-210 reprograms an oncogenic hypoxic circuit. J Am Chem Soc 139: 3446-3455. doi:10.1021/jacs.6b11273

Costales MG, Hoch DG, Abegg D, Childs-Disney JL, Velagapudi SP, Adibekian A, Disney MD. 2019. A designed small molecule inhibitor of a non-coding RNA sensitizes HER2 negative cancers to herceptin. J Am Chem Soc 141: 2960-2974. doi:10.1021/jacs $.8 \mathrm{~b} 10558$

Cullen BR. 1986. Trans-activation of human immunodeficiency virus occurs via a bimodal mechanism. Cell 46: 973-982. doi:10 .1016/0092-8674(86)90696-3

Davis B, Afshar M, Varani G, Murchie AlH, Karn J, Lentzen G, Drysdale M, Bower J, Potter AJ, Starkey ID, et al. 2004. Rational design of inhibitors of HIV-1 TAR RNA through the stabilisation of electrostatic "hot spots." J Mol Biol 336: 343-356. doi:10 .1016/j.jmb.2003.12.046

Delaglio F, Grzesiek S, Vuister GW, Zhu G, Pfeifer J, Bax A. 1995. NMRPipe: a multidimensional spectral processing system based on UNIX pipes. J Biomol NMR 6: 277-293. doi:10.1007/ BF00197809

Dibrov SM, Ding K, Brunn ND, Parker MA, Bergdahl BM, Wyles DL, Hermann T. 2012. Structure of a hepatitis $C$ virus RNA domain in complex with a translation inhibitor reveals a binding mode reminiscent of riboswitches. Proc Natl Acad Sci 109: 5223-5228. doi:10.1073/pnas.1118699109

Di Giorgio A, Duca M. 2019. Synthetic small-molecule RNA ligands: future prospects as therapeutic agents. Medchemcomm 10: 1242-1255. doi:10.1039/C9MD00195F

Disney MD. 2019. Targeting RNA with small molecules to capture opportunities at the intersection of chemistry, biology, and medicine. J Am Chem Soc 141: 6776-6790. doi:10.1021/jacs.8b13419

Disney MD, Winkelsas AM, Velagapudi SP, Southern M, Fallahi M, Childs-Disney JL. 2016. Inforna 2.0: a platform for the sequencebased design of small molecules targeting structured RNAs. ACS Chem Biol 11: 1720-1728. doi:10.1021/acschembio.6b00001

Donlic A, Morgan BS, Xu JL, Liu A, Roble C, Hargrove AE. 2018. Discovery of small molecule ligands for MALAT1 by tuning an RNA-binding scaffold. Angew Chem Int Ed Engl 57:1324213247 doi:10.1002/anie.201808823

Doua F, Miezan TW, Sanon Singaro JR, Boa Yapo F, Baltz T. 1996. The efficacy of pentamidine in the treatment of early-late stage Trypanosoma brucei gambiense trypanosomiasis. Am J Trop Med Hyg 55: 586-588. doi:10.4269/ajtmh.1996.55.586

Drake S, Lampasona V, Nicks HL, Schwarzmann SW. 1985. Pentamidine isethionate in the treatment of Pneumocystis carinii pneumonia. Clin Pharm 4: 507-516. doi:10.1093/ajhp/42.10.2332

Duca M, Malnuit V, Barbault F, Benhida R. 2010. Design of novel RNA ligands that bind stem-bulge HIV-1 TAR RNA. Chem Comm 46: 6162-6164. doi:10.1039/c0cc00645a

Edwards KJ, Jenkins TC, Neidle S. 1992. Crystal structure of a pentamidine-oligonucleotide complex: implications for DNA-binding properties. Biochemistry 31: 7104-7109. doi:10.1021/ bi00146a011

Ennifar E, Yusupov M, Walter P, Marquet R, Ehresmann B, Ehresmann C, Dumas P. 1999. The crystal structure of the dimerization initiation site of genomic HIV-1 RNA reveals an extended duplex with two adenine bulges. Structure 7: 1439-1449. doi:10 .1016/S0969-2126(00)80033-7

Faber C, Sticht H, Schweimer K, Rösch P. 2000. Structural rearrangements of HIV-1 Tat-responsive RNA upon binding of neomycin B. J Biol Chem 275: 20660-20666. doi:10.1074/jbc.M000920200

François B, Russell RJM, Murray JB, Aboul-ela F, Masquida B, Vicens Q, Westhof E. 2005. Crystal structures of complexes between aminoglycosides and decoding $A$ site oligonucleotides: role of the number of rings and positive charges in the specific binding leading to miscoding. Nucleic Acids Res 33: 56775690. doi:10.1093/nar/gki862

Freisz S, Lang K, Micura R, Dumas P, Ennifar E. 2008. Binding of aminoglycoside antibiotics to the duplex form of the HIV-1 genomic RNA dimerization initiation site. Angew Chem Int Ed Engl 47: 4110-4113. doi:10.1002/anie.200800726

Gagnon KT, Corey DR. 2019. Guidelines for experiments using antisense oligonucleotides and double-stranded RNAs. Nucleic Acid Ther 29: 116-122. doi:10.1089/nat.2018.0772

Ganser LR, Lee J, Rangadurai A, Merriman DK, Kelly ML, Kansal AD, Sathyamoorthy B, Al-Hashimi HM. 2018. High-performance virtual screening by targeting a high-resolution RNA dynamic ensemble. Nat Struct Mol Biol 25: 425-434. doi:10.1038/s41594-018-0062-4

Ganser LR, Chu CC, Bogerd HP, Kelly ML, Cullen BR, Al-Hashimi HM. 2020. Probing RNA conformational equilibria within the functional cellular context. Cell Rep 30: 2472-2480.e4. doi:10.1016/j.celrep .2020 .02 .004 
Geary RS, Norris D, Yu R, Bennett CF. 2015. Pharmacokinetics, biodistribution and cell uptake of antisense oligonucleotides. Adv Drug Deliv Rev 87: 46-51. doi:10.1016/j.addr.2015.01.008

Gelus N, Bailly C, Hamy F, Klimkait T, Wilson WD, Boykin DW. 1999. Inhibition of HIV-1 Tat-TAR interaction by diphenylfuran derivatives: effects of the terminal basic side chains. Bioorganic Med Chem 7: 1089-1096. doi:10.1016/S0968-0896(99)00041-3

Goddard TD, Kneller DG. 2006. Sparky—NMR assignment and integration software. University of California, San Francisco.

Gunanathan Jayaraj G, Ramasamy S, Bose D, Suryawanshi H, Lalwani M, Sivasubbu S, Maiti S. 2017. Aminoglycoside antibiotics perturb physiologically important microRNA contributing to drug toxicity. bioRxiv. doi:10.1101/137935

Haga CL, Velagapudi SP, Strivelli JR, Yang WY, Disney MD, Phinney DG. 2015. Small molecule inhibition of miR-544 biogenesis disrupts adaptive responses to hypoxia by modulating ATMmTOR signaling. ACS Chem Biol 10: 2267-2276. doi:10.1021/ acschembio.5b00265

Hamasaki K, Ueno A. 2001. Aminoglycoside antibiotics, neamine and its derivatives as potent inhibitors for the RNA-protein interactions derived from HIV-1 activators. Bioorg Med Chem Lett 11: $591-$ 594. doi:10.1016/S0960-894X(01)00005-1

Hamy F, Brondani V, Flörsheimer A, Stark W, Blommers MJJ, Klimkait T. 1998. A new class of HIV-1 Tat antagonist acting through Tat-TAR inhibition. Biochemistry 37: 5086-5095. doi:10 .1021/bi972947s

Han Q, Zhao Q, Fish S, Simonsen KB, Vourloumis D, Froelich JM, Wall D, Hermann T. 2005. Molecular recognition by glycoside pseudo base pairs and triples in an apramycin-RNA complex. Angew Chem Int Ed Engl 44: 2694-2700. doi:10.1002/anie .200500028

He M, Yuan D, Lin W, Pang R, Yu X, Yang M. 2005. Synthesis and assay of isoquinoline derivatives as HIV-1 Tat-TAR interaction inhibitors. Bioorg Med Chem Lett 15: 3978-3981. doi:10.1016/j.bmcl.2005 .01 .068

Hermann T. 2016. Small molecules targeting viral RNA. Wiley Interdiscip Rev RNA 7: 726-743. doi:10.1002/wrna.1373

Hermann T, Patel DJ. 2000. Adaptive recognition by nucleic acid aptamers. Science 287: 820-825. doi:10.1126/science.287 .5454 .820

Hermann T, Westhof E. 1998. Aminoglycoside binding to the hammerhead ribozyme: a general model for the interaction of cationic antibiotics with RNA. J Mol Biol 276: 903-912. doi:10.1006/jmbi .1997 .1590

Hermann T, Westhof E. 1999. Docking of cationic antibiotics to negatively charged pockets in RNA folds. J Med Chem 42: 1250-1261. doi:10.1021/jm981108g

Holbrook SR, Sussman JL, Warrant RW, Church GM, Kim SH. 1977. RNA-ligand interactions: (I) Magnesium binding sites in yeast tRNA. Nucleic Acids Res 4: 2811-2820. doi:10.1093/nar/4.8.2811

Hong S, Harris KA, Fanning KD, Sarachan KL, Frohlich KM, Agris PF. 2015. Evidence that antibiotics bind to human mitochondrial ribosomal RNA has implications for aminoglycoside toxicity. J Biol Chem 290: 19273-19286. doi:10.1074/jbc.M115.655092

Hwang S, Tamilarasu N, Kibler K, Cao H, Ali A, Ping YH, Jeang KT, Rana TM. 2003. Discovery of a small molecule Tat-trans-activation-responsive RNA antagonist that potently inhibits human immunodeficiency virus-1 replication. J Biol Chem 278: 39092 39103. doi:10.1074/jbc.M301749200

Ironmonger A, Whittaker B, Baron AJ, Clique B, Adams CJ, Ashcroft AE, Stockley PG, Nelson A. 2007. Scanning conformational space with a library of stereo- and regiochemically diverse aminoglycoside derivatives: the discovery of new ligands for RNA hairpin sequences. Org Biomol Chem 5: 1081-1086. doi:10.1039/b618683a
Kondo J, Hainrichson M, Nudelman I, Shallom-Shezifi D, Barbieri CM, Pilch DS, Westhof E, Baasov T. 2007. Differential selectivity of natural and synthetic aminoglycosides towards the eukaryotic and prokaryotic decoding A sites. Chembiochem 8: 1700-1709. doi:10.1002/cbic.200700271

Lee M-K, Bottini A, Kim M, Bardaro MF, Zhang Z, Pellecchia M, Choi B$S$, Varani G. 2014. A novel small-molecule binds to the influenza $A$ virus RNA promoter and inhibits viral replication. Chem Commun 50: 368-370. doi:10.1039/C3CC46973E

Lieberman J. 2018. Tapping the RNA world for therapeutics. Nat Struct Mol Biol 25: 357-364. doi:10.1038/s41594-018-0054-4

Lu XJ, Bussemaker HJ, Olson WK. 2015. DSSR: an integrated software tool for dissecting the spatial structure of RNA. Nucleic Acids Res 43: e142.

Luedtke NW, Tor Y. 2003. Fluorescence-based methods for evaluating the RNA affinity and specificity of HIV-1 rev-RRE inhibitors. Biopolymers 70: 103-119. doi:10.1002/bip.10428

Malim MH, Hauber J, Fenrick R, Cullen BR. 1988. Immunodeficiency virus rev trans-activator modulates the expression of the viral regulatory genes. Nature 335: 181-183. doi:10.1038/335181a0

Malim MH, Hauber J, Le SY, Maizel JV, Cullen BR. 1989. The HIV-1 rev trans-activator acts through a structured target sequence to activate nuclear export of unspliced viral mRNA. Nature 338: 254257. doi:10.1038/338254a0

Malim MH, Tiley LS, McCarn DF, Rusche JR, Hauber J, Cullen BR. 1990. HIV-1 structural gene expression requires binding of the rev trans-activator to its RNA target sequence. Cell 60: 675-683. doi:10.1016/0092-8674(90)90670-A

Matsui M, Corey DR. 2017. Non-coding RNAs as drug targets. Nat Rev Drug Discov 16: 167-179. doi:10.1038/nrd.2016.117

Matsumoto C, Hamasaki K, Mihara H, Ueno A. 2000. A high-throughput screening utilization intramolecular fluorescence resonance energy transfer for the discovery of the molecules that bind HIV1 TAR RNA specifically. Bioorg Med Chem Lett 10: 1857-1861. doi:10.1016/S0960-894X(00)00359-0

McCown PJ, Corbino KA, Stav S, Sherlock ME, Breaker RR. 2017. Riboswitch diversity and distribution. RNA 23: 995-1011. doi:10 $.1261 /$ rna.061234.117

Mei HY, Mack DP, Galan AA, Halim NS, Heldsinger A, Loo JA, Moreland DW, Sannes-Lowery KA, Sharmeen L, Truong HN, et al. 1997. Discovery of selective, small-molecule inhibitors of RNA complexes-I. The Tat protein/TAR RNA complexes required for HIV-1 transcription. Bioorg Med Chem 5: 1173-1184. doi:10 .1016/S0968-0896(97)00064-3

Mei HY, Cui M, Heldsinger A, Lemrow SM, Loo JA, Sannes-Lowery KA, Sharmeen L, Czarnik AW. 1998. Inhibitors of protein-RNA complexation that target the RNA: specific recognition of human immunodeficiency virus type 1 TAR RNA by small organic molecules. Biochemistry 37: 14204-14212. doi:10.1021/ bi981308u

Mendell JR, Rodino-Klapac LR, Sahenk Z, Roush K, Bird L, Lowes LP, Alfano L, Gomez AM, Lewis S, Kota J, et al. 2013. Eteplirsen for the treatment of Duchenne muscular dystrophy. Ann Neurol 74: 637-647. doi:10.1002/ana.23982

Miao Z, Westhof E. 2017. RNA structure: advances and assessment of 3D structure prediction. Annu Rev Biophys 46: 483-503. doi:10 .1146/annurev-biophys-070816-034125

Michael K, Tor Y. 1998. Designing novel RNA binders. Chem Eur J 4: 2091-2098. doi:10.1002/(SICl)1521-3765(19981102)4:11<2091:: AID-CHEM2091>3.0.CO;2-3

Mischiati C, Jeang K-T, Feriotto G, Breda L, Borgatti M, Bianchi N, Gambari R. 2001. Aromatic polyamidines inhibiting the tat-induced HIV-1 transcription recognize structured TAR-RNA. Antisense Nucleic Acid Drug Dev 11: 209-217 doi:10.1089/ 108729001317022214 
Mischiati C, Finotti A, Sereni A, Boschetti S, Baraldi PG, Romagnoli R, Feriotto $G$, Jeang K-T, Bianchi N, Borgatti M, et al. 2004. Binding of hybrid molecules containing pyrrolo [2,1-c][1,4]benzodiazepine (PBD) and oligopyrrole carriers to the human immunodeficiency type 1 virus TAR-RNA. Biochem Pharmacol 67: 401-410. doi:10 .1016/j.bcp.2003.09.009

Mishra SK, Kumar A. 2016. NALDB: nucleic acid ligand database for small molecules targeting nucleic acid. Database 2016: baw002. doi:10.1093/database/baw002

Moore PB. 1999. Structural motifs in RNA. Annu Rev Biochem 68: 287-300. doi:10.1146/annurev.biochem.68.1.287

Morgan BS, Sanaba BG, Donlic A, Karloff DB, Forte JE, Zhang Y, Hargrove AE. 2019. R-BIND: an interactive database for exploring and developing RNA-targeted chemical probes. ACS Chem Biol 14: 2691-2700. doi:10.1021/acschembio.9b00631

Murchie AlH, Davis B, Isel C, Afshar M, Drysdale MJ, Bower J, Potter AJ, Starkey ID, Swarbrick TM, Mirza S, et al. 2004. Structure-based drug design targeting an inactive RNA conformation: exploiting the flexibility of HIV-1 TAR RNA. J Mol Biol 336: 625-638. doi:10.1016/j.jmb.2003.12.028

Nahar S, Bose D, Kumar Panja S, Saha S, Maiti S. 2014. Anti-cancer therapeutic potential of quinazoline based small molecules via global upregulation of miRNAs. Chem Comm 50: 4639-4642. doi:10.1039/c3cc49337g

Naro Y, Ankenbruck N, Thomas M, Tivon Y, Connelly CM, Gardner L, Deiters A. 2018. Small molecule inhibition of microRNA miR-21 rescues chemosensitivity of renal-cell carcinoma to topotecan. $J$ Med Chem 61: 5900-5909. doi:10.1021/acs.jmedchem.7b01891

Orlovsky NI, Al-Hashimi HM, Oas TG. 2020. Exposing hidden high-affinity RNA conformational states. J Am Chem Soc 142: 907-921. doi:10.1021/jacs.9b10535

Palacino J, Swalley SE, Song C, Cheung AK, Shu L, Zhang X, Van Hoosear M, Shin Y, Chin DN, Keller CG, et al. 2015. SMN2 splice modulators enhance U1-pre-mRNA association and rescue SMA mice. Nat Chem Biol 11: 511-517. doi:10.1038/nchembio.1837

Parsons J, Castaldi MP, Dutta S, Dibrov SM, Wyles DL, Hermann T. 2009. Conformational inhibition of the hepatitis $C$ virus internal ribosome entry site RNA. Nat Chem Biol 5: 823-825. doi:10.1038/ nchembio. 217

Pascale L, López González A, Di Giorgio A, Gaysinski M, Closa JT, Estrada Tejedor R, Azoulay S, Patino N, Teixido Closa J. 2016. Deciphering structure-activity relationships in a series of Tat/TAR inhibitors. J Biomol Struct Dyn 34: 2327-2338. doi:10.1080/ 07391102.2015 .1114971

Patwardhan NN, Ganser LR, Kapral GJ, Eubanks CS, Lee J, Sathyamoorthy B, Al-Hashimi HM, Hargrove AE. 2017. Amiloride as a new RNA-binding scaffold with activity against HIV-1 TAR. Medchemcomm 8: 1022-1036. doi:10.1039/C6MD00729E

Patwardhan NN, Cai Z, Newson CN, Hargrove AE. 2019. Fluorescent peptide displacement as a general assay for screening small molecule libraries against RNA. Org Biomol Chem 17: 1778-1786. doi:10.1039/C8OB02467G

Pitt SW, Zhang Q, Patel DJ, Al-Hashimi HM. 2005. Evidence that electrostatic interactions dictate the ligand-induced arrest of RNA global flexibility. Angew Chem Int Ed Engl 44: 3412-3415. doi:10.1002/anie.200500075

Prado S, Beltrán M, Coiras M, Bedoya LM, Alcamí J, Gallego J. 2016. Bioavailable inhibitors of HIV-1 RNA biogenesis identified through a rev-based screen. Biochem Pharmacol 107: 14-28. doi:10.1016/ j.bcp.2016.02.007

Puglisi JD, Tan R, Calnan BJ, Frankel AD, Williamson JR. 1992. Conformation of the TAR RNA-arginine complex by NMR spectroscopy. Science 257: 76-80. doi:10.1126/science.1621097

Ratmeyer L, Zapp ML, Green MR, Vinayak R, Kumar A, Boykin DW, David Wilson W. 1996. Inhibition of HIV-1 Rev-RRE interaction by diphenylfuran derivatives. Biochemistry 35: 13689-13696. doi:10.1021/bi960954v

Ratni H, Ebeling M, Baird J, Bendels S, Bylund J, Chen KS, Denk N, Feng Z, Green L, Guerard M, et al. 2018. Discovery of risdiplam, a selective survival of motor neuron-2 (SMN2) gene splicing modifier for the treatment of spinal muscular atrophy (SMA). J Med Chem 61: 6501-6517. doi:10.1021/acs.jmedchem.8b00741

Richter S, Parolin C, Gatto B, Del Vecchio C, Brocca-Cofano E, Fravolini A, Palù G, Palumbo M. 2004. Inhibition of human immunodeficiency virus type 1 Tat-trans-activation-responsive region interaction by an antiviral quinolone derivative. Antimicrob Agents Chemother 48: 1895-1899. doi:10.1128/AAC.48.5.18951899.2004

Rzuczek SG, Colgan LA, Nakai Y, Cameron MD, Furling D, Yasuda R, Disney MD. 2017. Precise small-molecule recognition of a toxic CUG RNA repeat expansion. Nat Chem Biol 13: 188-193. doi:10 .1038/nchembio.2251

Sarti GM. 1989. Aerosolized pentamidine in HIV. Promising new treatment for Pneumocystis carinii pneumonia. Postgrad Med 86: 5469. doi:10.1080/00325481.1989.11704352

Sathyamoorthy B, Lee J, Kimsey I, Ganser LR, Al-Hashimi H. 2014. Development and application of aromatic $\left[{ }^{13} \mathrm{C},{ }^{1} \mathrm{H}\right]$ SOFASTHMOC NMR experiment for nucleic acids. J Biomol NMR 60: 77-83. doi:10.1007/s10858-014-9856-9

Schmidt MF. 2014. Drug target miRNAs: chances and challenges. Trends Biotechnol 32: 578-585. doi:10.1016/j.tibtech.2014.09 .002

Schwalbe H, Buck J, Fürtig B, Noeske J, Wöhnert J. 2007. Structures of RNA switches: insight into molecular recognition and tertiary structure. Angew Chem Int Ed Engl 46: 1212-1219. doi:10 .1002/anie.200604163

Shi Y, Parag S, Patel R, Lui A, Murr M, Cai J, Patel NA. 2019. Stabilization of IncRNA GAS5 by a small molecule and its implications in diabetic adipocytes. Cell Chem Biol 26: 319-330.e6. doi:10.1016/j.chembiol.2018.11.012

Shin YH, Choi BS, Kim KC, Kang C, Kim K, Yoon CH. 2017. Development of a dual reporter screening assay for distinguishing the inhibition of HIV Tat-mediated transcription from off-target effects. J Virol Methods 249: 1-9. doi:10.1016/j.jviromet.2017 .08 .005

Soto-Mancipe J, Grogl M, Berman JD. 1993. Evaluation of pentamidine for the treatment of cutaneous leishmaniasis in Colombia. Clin Infect Dis 16: 417-425. doi:10.1093/clind/16.3.417

Stelzer AC, Frank AT, Kratz JD, Swanson MD, GonzalezHernandez MJ, Lee J, Andricioaei I, Markovitz David M, AlHashimi HM. 2011. Discovery of selective bioactive small molecules by targeting an RNA dynamic ensemble. Nat Chem Biol 7: 553-559. doi:10.1038/nchembio.596

Sun T, Zhang Y. 2008. Pentamidine binds to tRNA through non-specific hydrophobic interactions and inhibits aminoacylation and translation. Nucleic Acids Res 36: 1654-1664. doi:10.1093/nar/ gkm1180

Sztuba-Solinska J, Shenoy SR, Gareiss P, Krumpe LRH, Le Grice SFJ, O'Keefe BR, Schneekloth JS. 2014. Identification of biologically active, HIV TAR RNA-binding small molecules using small molecule microarrays. J Am Chem Soc 136: 8402-8410. doi:10.1021/ ja502754f

Tanious FA, Veal JM, Buczak H, Ratmeyer LS, Wilson WD. 1992. DAPI (4', 6-diamidino-2-Phenylindóle) binds differently to DNA and RNA: minor-groove binding at AT sites and intercalation at AU sites. Biochemistry 31: 3103-3112. doi:10.1021/bi00127a010

Tanner NK, Cech TR. 1985. Self-catalyzed cyclization of the intervening sequence RNA of Tetrahymena: inhibition by intercalating dyes. Nucleic Acids Res 13: 7741-7758. doi:10.1093/nar/13 21.7741 


\section{Kelly et al.}

Thomas JR, Hergenrother PJ. 2008. Targeting RNA with small molecules. Chem Rev 108: 1171-1224. doi:10.1021/cr0681546

Thorne N, Inglese J, Auld DS. 2010. Illuminating insights into firefly luciferase and other bioluminescent reporters used in chemical biology. Chem Biol 17: 646-657. doi:10.1016/j.chembiol.2010 .05 .012

Tibodeau JD, Fox PM, Ropp PA, Theil EC, Thorp HH. 2006. The upregulation of ferritin expression using a small-molecule ligand to the native mRNA. Proc Natl Acad Sci 103: 253-257. doi:10 .1073/pnas.0509744102

Tiley LS, Madore SJ, Malim MH, Cullen BR. 1992. The VP16 transcription activation domain is functional when targeted to a promoterproximal RNA sequence. Genes Dev 6: 2077-2087. doi:10.1101/ gad.6.11.2077

Turner JJ, Ivanova GD, Verbeure B, Williams D, Arzumanov AA, Abes SS, Lebleu B, Gait MJ. 2005. Cell-penetrating peptide conjugates of peptide nucleic acids (PNA) as inhibitors of HIV-1 Tatdependent trans-activation in cells. Nucleic Acids Res 33: 68376849. doi:10.1093/nar/gki991

van Deutekom JC, de Kimpe SJ, Campion G V. 2013. Antisense oligonucleotides as personalized medicine for Duchenne muscular dystrophy. Drug Discov Today Ther Strateg 10: e149-e156. doi:10 .1016/j.ddstr.2013.04.001

Velagapudi SP, Gallo SM, Disney MD. 2014. Sequence-based design of bioactive small molecules that target precursor microRNAs. Nat Chem Biol 10: 291-297. doi:10.1038/nchembio.1452

Verhelst SHL, Michiels PJA, Van Der Mare GA, Van Boeckel CAA, Van Boom JH. 2004. Surface plasmon resonance evaluation of various aminoglycoside-RNA hairpin interactions reveals low degree of selectivity. Chembiochem 5: 937-942. doi:10.1002/cbic .200300819

Walter F, Vicens Q, Westhof E. 1999. Aminoglycoside-RNA interactions. Curr Opin Chem Biol 3: 694-704. doi:10.1016/S13675931(99)00028-9

Warf MB, Nakamori M, Matthys CM, Thornton CA, Berglund JA. 2009. Pentamidine reverses the splicing defects associated with myoton- ic dystrophy. Proc Natl Acad Sci 106: 18551-18556. doi:10.1073/ pnas.0903234106

Warner KD, Hajdin CE, Weeks KM. 2018. Principles for targeting RNA with drug-like small molecules. Nat Rev Drug Discov 17: 547-558. doi:10.1038/nrd.2018.93

White SA, Draper DE. 1987. Single base bulges in small RNA hairpins enhance ethidium binding and promote an allosteric transition. Nucleic Acids Res 15: 4049-4064. doi:10.1093/nar/15 .10 .4049

Wong C-H, Hendrix M, Scott Priestley E, Greenberg WA. 1998. Specificity of aminoglycoside antibiotics for the A-site of the decoding region of ribosomal RNA. Chem Biol 5: 397-406. doi:10 .1016/S1074-5521(98)90073-4

Xie J, Talaska AE, Schacht J. 2011. New developments in aminoglycoside therapy and ototoxicity. Hear Res 281: 28-37. doi:10.1016/j .heares.2011.05.008

Zeiger M, Stark S, Kalden E, Ackermann B, Ferner J, Scheffer U, ShojaBazargani F, Erdel V, Schwalbe H, Göbel MW. 2014. Fragment based search for small molecule inhibitors of HIV-1 Tat-TAR. Bioorg Med Chem Lett 24: 5576-5580. doi:10.1016/j.bmcl.2014 .11 .004

Zhang Y. 2002. Pentamidine inhibits catalytic activity of group I intron Ca.LSU by altering RNA folding. Nucleic Acids Res 30: 2961-2971. doi:10.1093/nar/gkf394

Zhang P, Park HJ, Zhang J, Junn E, Andrews RJ, Velagapudi SP, Abegg D, Vishnu K, Costales MG, Childs-Disney JL, et al. 2020. Translation of the intrinsically disordered protein $\alpha$-synuclein is inhibited by a small molecule targeting its structured mRNA. Proc Natl Acad Sci 117: 1457-1467. doi:10.1073/pnas .1905057117

Zheng $H$, Shabalin IG, Handing KB, Bujnicki JM, Minor W. 2015. Magnesium-binding architectures in RNA crystal structures: validation, binding preferences, classification and motif detection. Nucleic Acids Res 43: 3789-3801. doi:10.1093/nar/ gkv225 

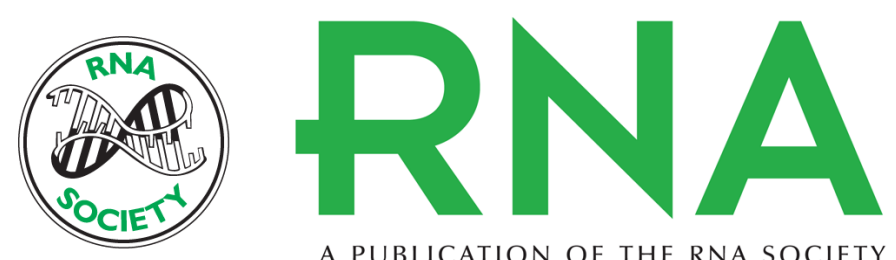

A PUBLICATION OF THE RNA SOCIETY

\section{Understanding the characteristics of nonspecific binding of drug-like compounds to canonical stem-loop RNAs and their implications for functional cellular assays}

Megan L. Kelly, Chia-Chieh Chu, Honglue Shi, et al.

RNA 2021 27: $12-26$ originally published online October 7, 2020

Access the most recent version at doi:10.1261/rna.076257.120

Supplemental Material

References

Creative Commons License

Email Alerting Service
http://rnajournal.cshlp.org/content/suppl/2020/10/07/rna.076257.120.DC1

This article cites 118 articles, 14 of which can be accessed free at: http://rnajournal.cshlp.org/content/27/1/12.full.html\#ref-list-1

This article is distributed exclusively by the RNA Society for the first 12 months after the full-issue publication date (see http://rnajournal.cshlp.org/site/misc/terms.xhtml). After 12 months, it is available under a Creative Commons License (Attribution-NonCommercial 4.0 International), as described at http://creativecommons.org/licenses/by-nc/4.0/.

Receive free email alerts when new articles cite this article - sign up in the box at the top right corner of the article or click here.

To subscribe to RNA go to:

http://rnajournal.cshlp.org/subscriptions 